"نشريه علوم زراعى ايران"

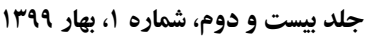

مقاله يخوهشى

ارزيابى برهمكنش زنوتيڤ در محيط در آزمايشهاى ناحيهاى عملكرد زنوتيڤهاى كندم دوروم

(Triticum turgidum var, durum L.)

Evaluation of genotype $\times$ environment interaction in durum wheat

(Triticum turgidum var. durum L.) regional yield trials

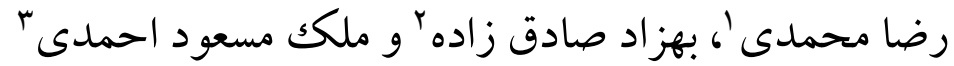

جצ'ינים

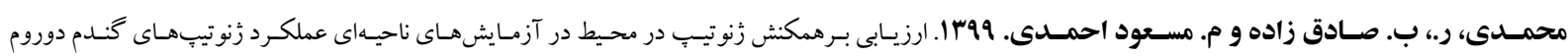

(Triticum turgidum var. durum L.)

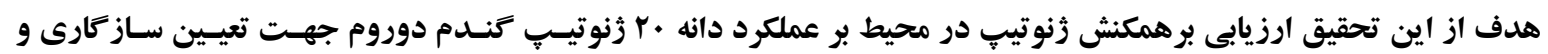

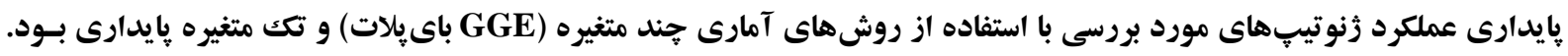

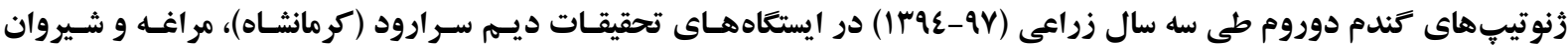

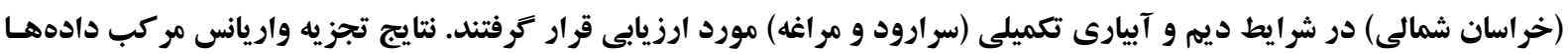

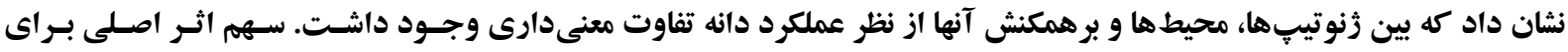

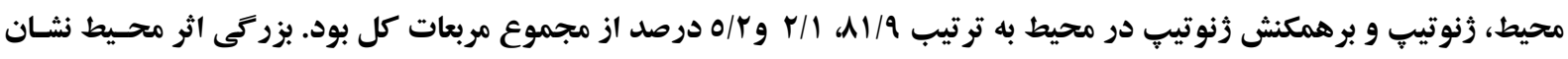

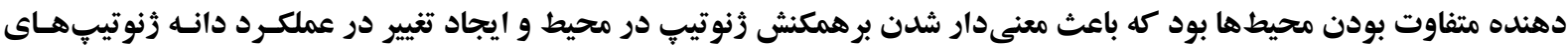

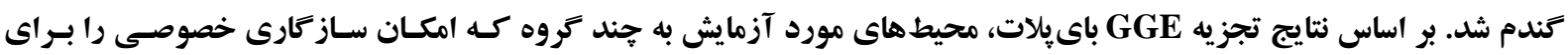

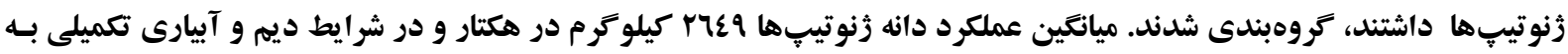

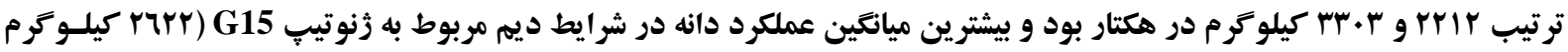

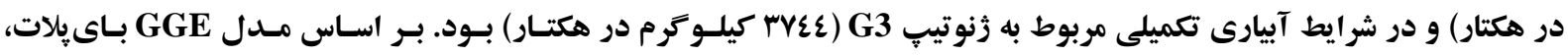

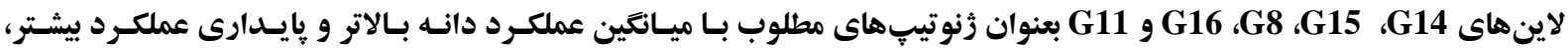

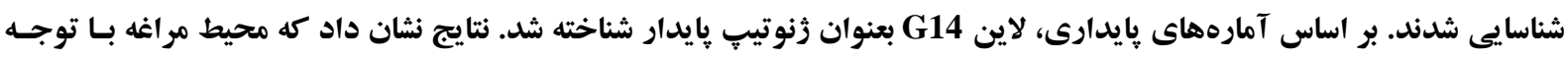

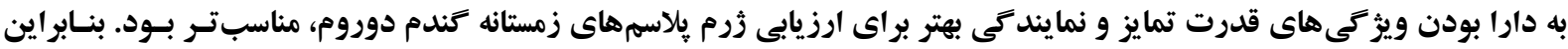

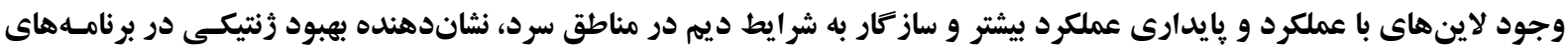

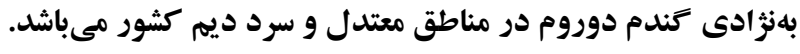

وازههاى كليدى: برهمكنش زنوتيب در محيط، پايدارى عملكرد، ساز كارى، كندم دوروم و GGE باىيلات.

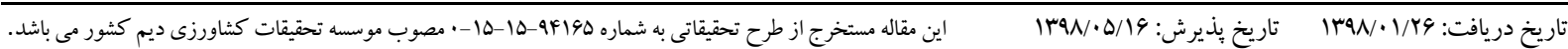

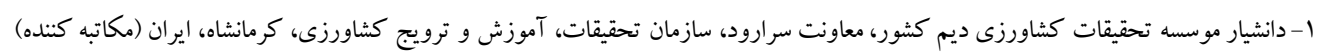

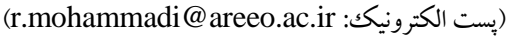

r-دانشيار موسسه تحقيقات كشاورزى ديم كشور، سازمان تحقيقات، آموزش و ترويج كشاورزى، مراغه، ايران

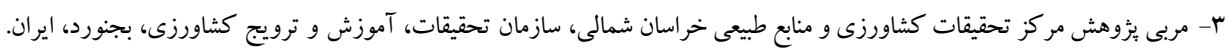


محيط و تعيين زنوتيبهاى بايدار و سـاز كار بـه شـرايط اقليمى مختلف، نقـش مهمسى در شناسـايى زنوتيبهـاى

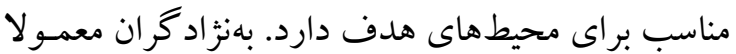

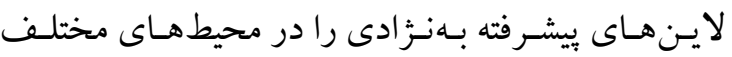

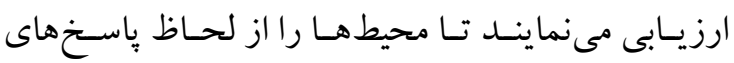

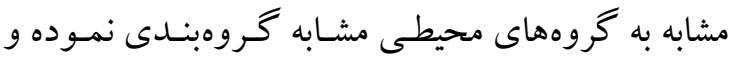

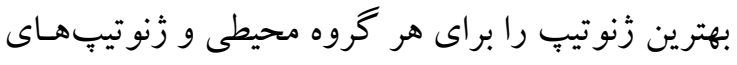

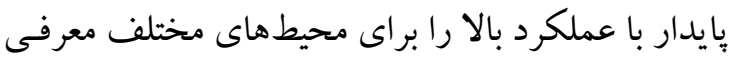

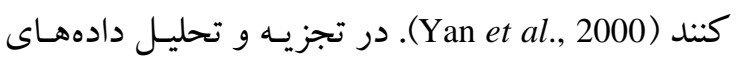
حاصل از آزمايش هاى مزرعهاى، محيط مسى توانـد هـر

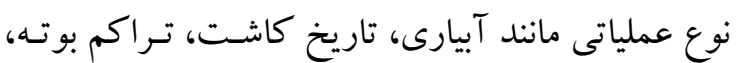

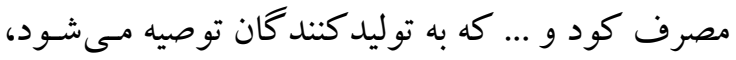
در نظر گرفته شود (Balalić et al., 2012).

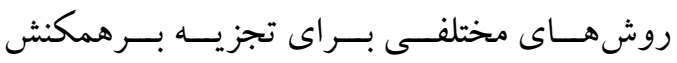

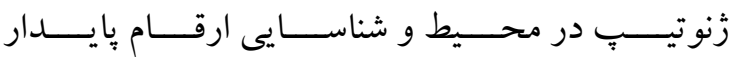
بـراى محيطهـاى مختلـف بيشـنهاد شـده اسـت كـه هـر

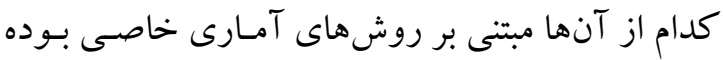

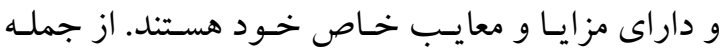

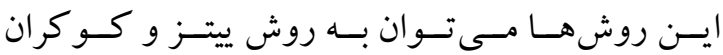
O جلاسـتد و يترسـون (Plaisted and Peterson, 1959)،

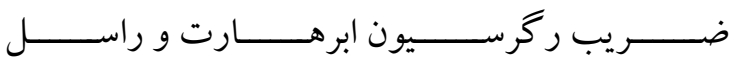
(Eberhart and Russell, 1966) و فينلى و ويلكينسون Finlay and Wilkinson, 1963)، اكـووالانس ريـك وتك (Wricke, 1962) (W.

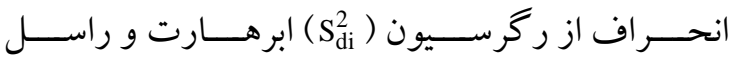

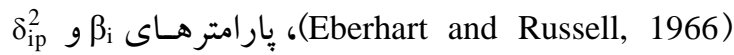
ير كينــز و جينكـــز (Perkins and Jinks, 1968)،

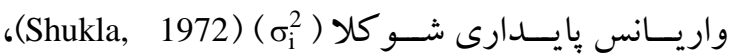
آمارههـــاى نإِــارامترى (Nassar and Huhn, 1987)

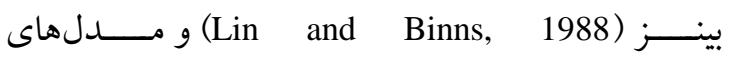
(Gabriel, 1971; Gauch and Zobel, 1997; بـاى يلات Yan et al., 2000)

\section{مقدمه}

كُندم دوروم با دانههاى سخت، حاوى بروتئين بالا و

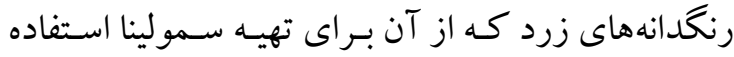

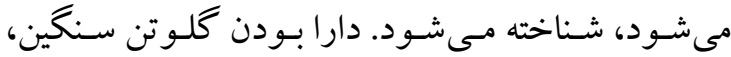

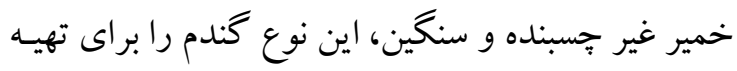

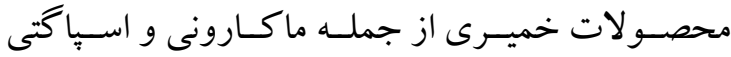

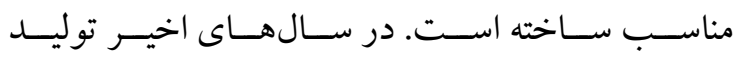

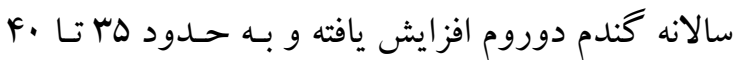
ميليون تن رسيده است. قسمت اعظم سطح زير كشت و و و

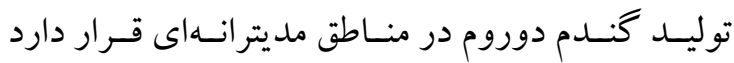
و باوجود اينكه ايران يكى (Able and Atienza, 2014)

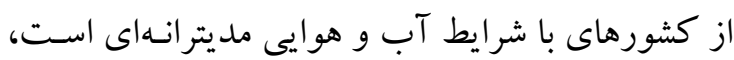

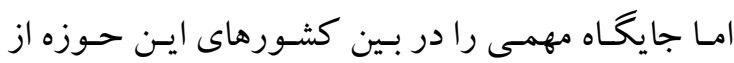
لحاظ توليد گنـدم دوروم نـدارد (Nachit et al., 1998). مناطق وسيعى از ايران براى توليد كندم دوروم با كيفيت

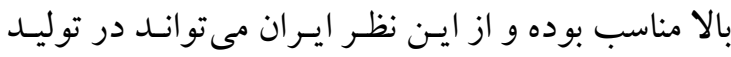

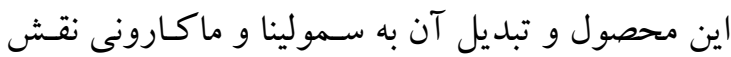
موثرى در بازارهاى جهانى داشته باشـد، امـا سططح زيـر

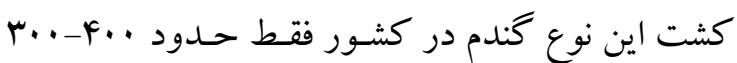

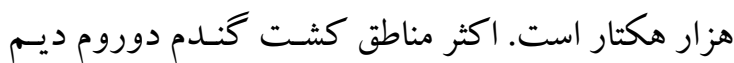

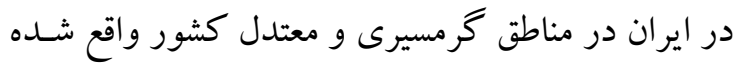

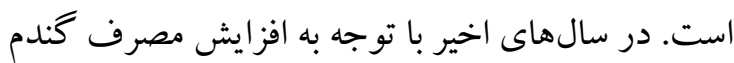

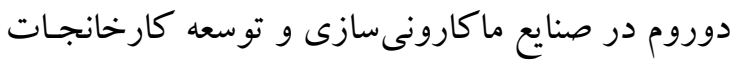

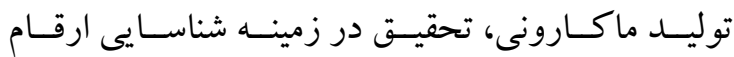

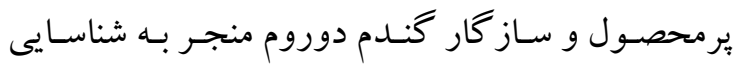

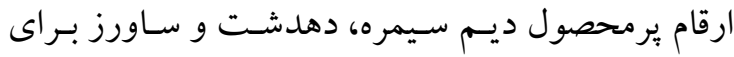

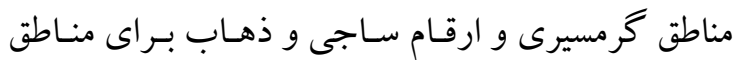

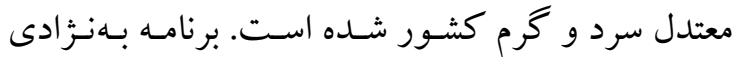
كندم دوروم در شرايط ديم تا كنون به شناسـايى رقمى درى مناسب براى شرايط سردسير كشور منجر نشده است كه دور نه

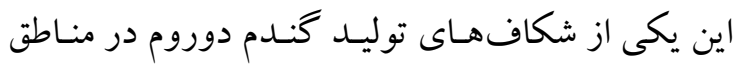
سرد مىباشد. ارزيابى زنوتيِ هاى حاصل از برنامـهــاى اصـلاحى

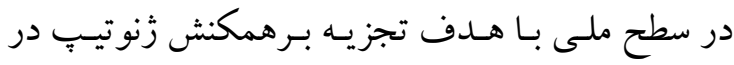




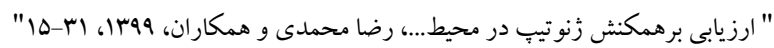

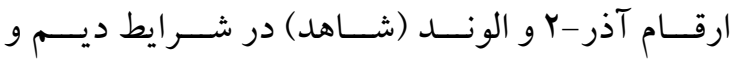

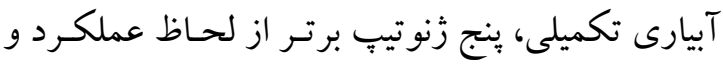

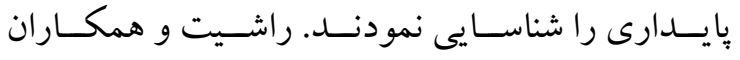

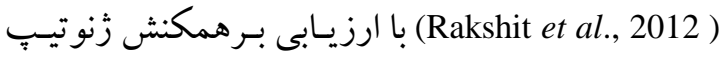

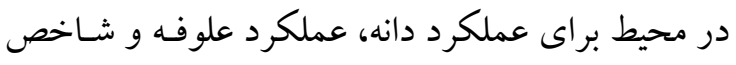

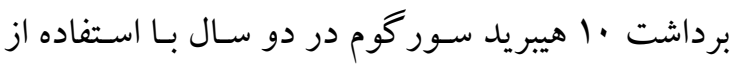

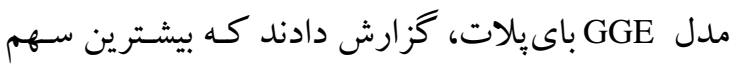

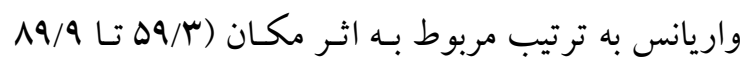

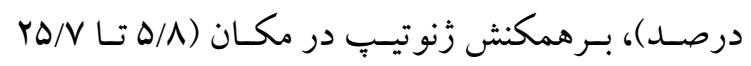

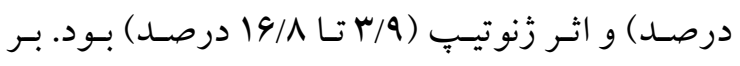

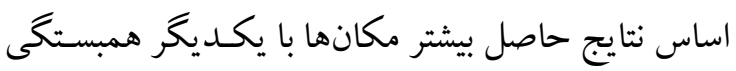

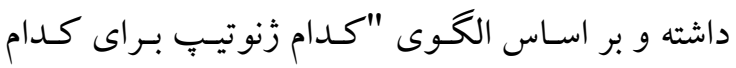

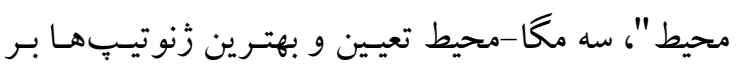
اساس هر مخا-محيط شناسايى شد.

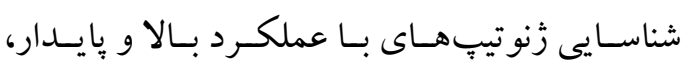
مهم ترين هدف برنامههاى بهنز ادى تحـت شـر ايط متغيـر

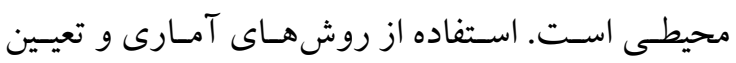

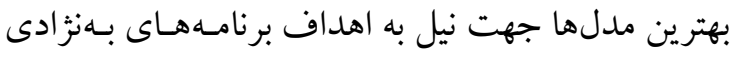

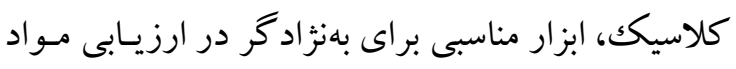

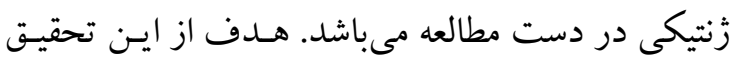

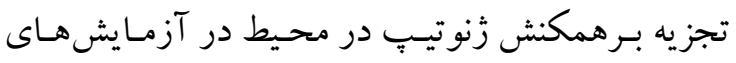

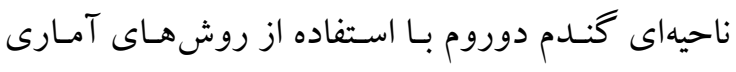

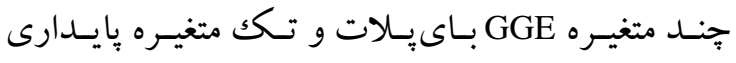

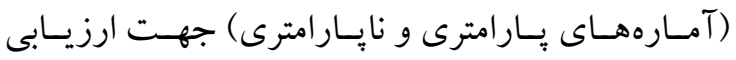

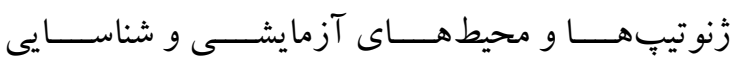

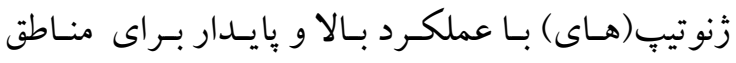

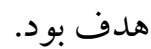

\section{مواد و روشها}

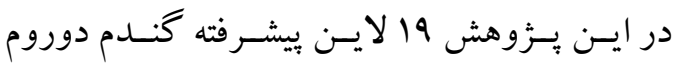

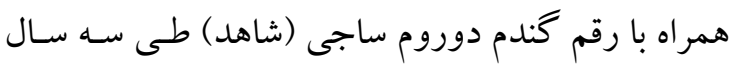

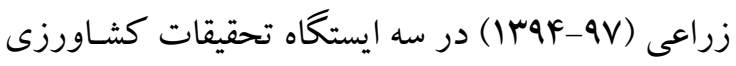

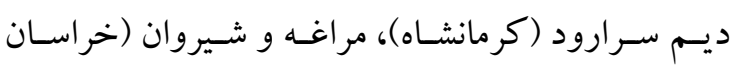

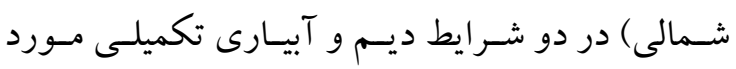

اصلى مىباشند، اشاره نمود. يكى از روشهـاى آمـارى

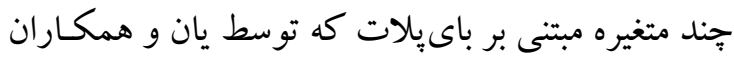
(Yan et al., 2000)

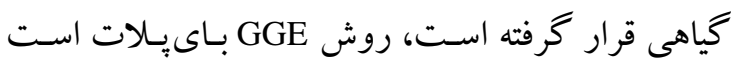

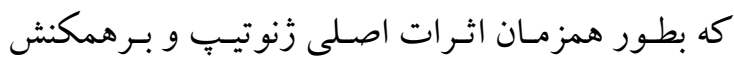

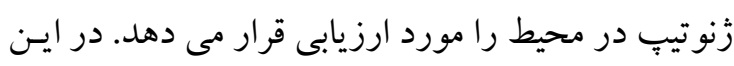

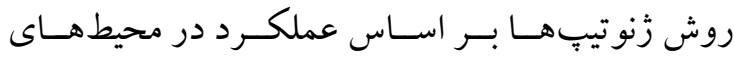
مختلف، تر كيب بايدارى و عملكرد، توانايى محيطهـيا

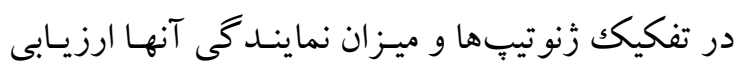

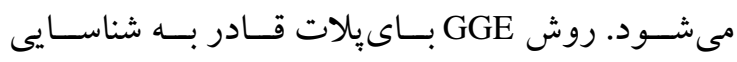

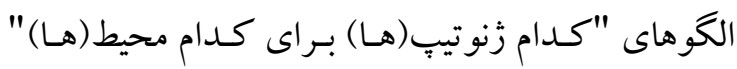
مىباشد كه اين موضوع در تعيين (Which-won-where)

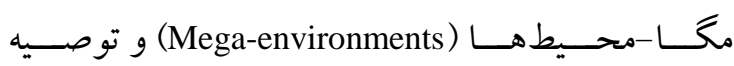

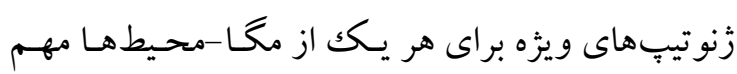

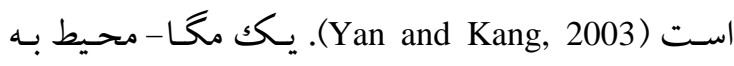

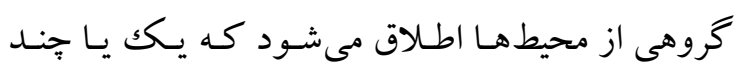

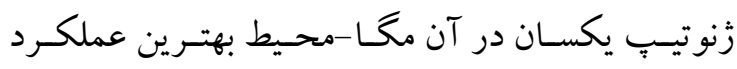
(واكنش محيطى) را داشته باشند (Yan et al., 2000). بـا

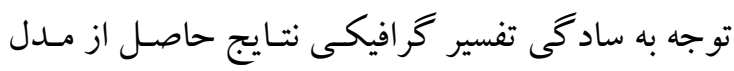

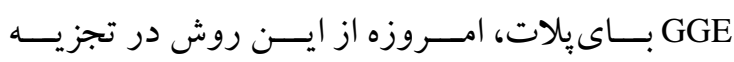
برهمكنش زنوتيّ در محيط بصورت كسترده استنفاده

$$
\text { مى شود. }
$$

يـان و همكـاران (Yan et al., 2000) بـا اسـتفاده

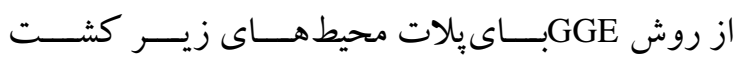

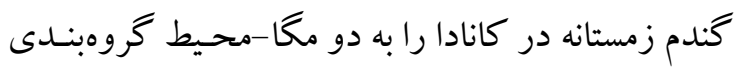

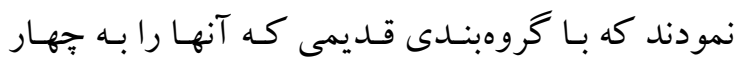
كروه تقسيم مى كـرد، متفـاوت بـود. شـارما و همكـاران (Sharma et al., 2010)

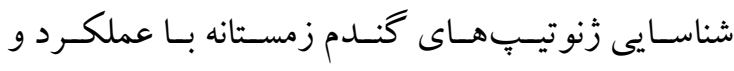

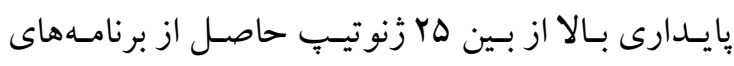

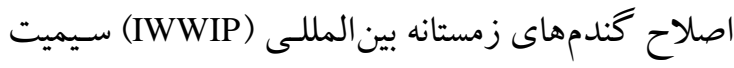

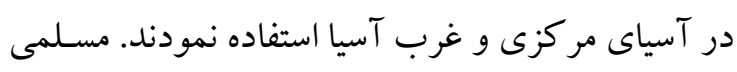

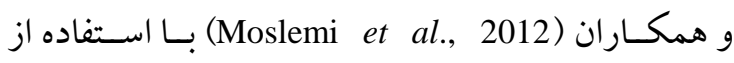

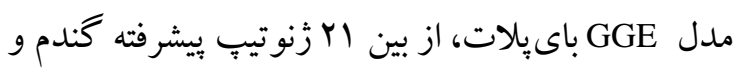


آزمايشى اسـتفاده شـد. ســـس تجزيسه واريـانس مركـب بر ایى عملكرد دانه به منظور بررسى اثر محيط، زنوتيبٍ و

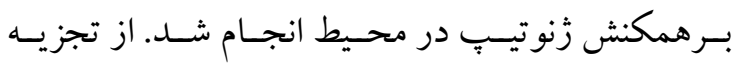
كر افيكـى GGE بــاى يـلات بــر اى تجزيـهـ بــرهمكنش زنوتيب در محيط اسـتفاده شـد. تجزيسه GGE بـاى بلات

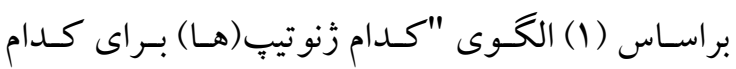

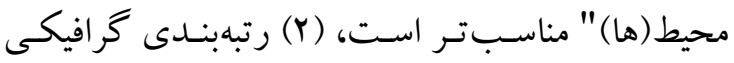
زنو تيبٍها بر اسـاس تر كيـب همزمـان ميـانگين عملكـرد

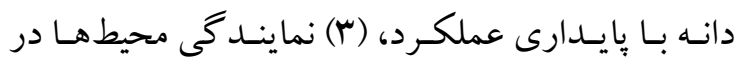

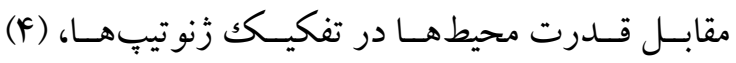

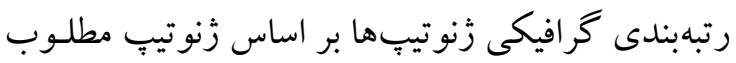
و (ه) گرووبندى محيطها بر اساس ميـزان تشـابه و عـدم تشابه آنها در تفكيكك زنوتيبهــا انجـام شـد. بـه منظـور

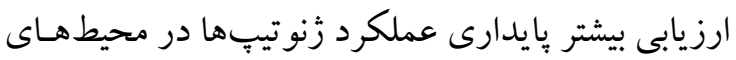
مورد بررسى از آمارههـاى بِايسـارى ضـريب ركرسيون Finlay and Wilkinson, 1963) (b) از ر خرسيون (Eberhart and Russell, 1966) (S'di)
ارزيابى قرار كرفتند (جدولهـاى او Y). آزمـايشهـى آبيارى تكميلى در ايستخاههاى سرارود و مراغه انجـام و

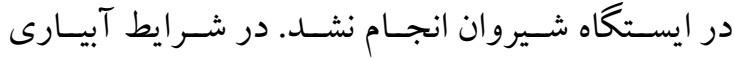
تكميلى دو بار آبيـارى (جمعـا حسدود ·9 ميلى ليتـر) از آغاز دوره كلدهى تا مرحلـه يـر شــن دانـه انجـام شـــ. زمين محـل اجـراى آزمـايشهـا در سـال قبـل بصـورت آيش بـود. هـر آزمـايش در هـر محـيط در قالـب طـرح بلو ككهـاى كامـل تصـادفى و در سـه تكــار اجـرا شـد. بذرهاى هر زُنوتيّ در شش خط شش متـرى بـا فاصـله خطوط ·· سانتى متر در كرتهايى به مسـاحت V/Y متـر

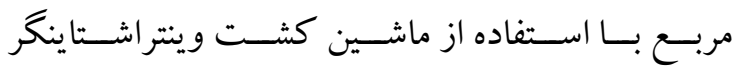

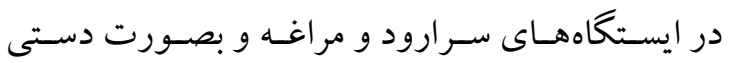
در ايستخاه شيروان كشت شدند. ميزان كـود مـورد نيـاز بـر اسـاس توصسيه كارشناسـان خـاكك و آب بـه خـاكى ماده شد.

از آزمون كولمـو گروف-اسـميرنوف بـراى آزمـون

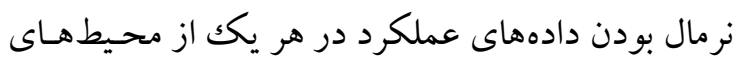

جدول ا - كد و مشخصات · r زنوتيب كندم دوروم مورد ارزيابى

Table 1. Code and characteristics of 20 durum wheat genotypes

\begin{tabular}{|c|c|c|}
\hline $\begin{array}{c}\text { كد } \\
\text { Code }\end{array}$ & $\begin{array}{c}\text { نام/شجره } \\
\text { Name/Pedigree }\end{array}$ & $\begin{array}{l}\text { Origin } \\
\text { Oنشاء }\end{array}$ \\
\hline G1 & Saji (Check) & Iran \\
\hline $\mathrm{G} 2$ & RASCON_37/4/MAGH72/RUFO//ALG86... & CIMMYT \\
\hline G3 & $61-130$ & Turkey \\
\hline G4 & $61-130 / 414-44 / / 377-2 / 4 /$ Df $21-72 / / 61-130 \ldots$ & Iran \\
\hline G5 & $61-130 / 414-44 / / 377-2 / 4 /$ Df $21-72 / / \ldots$ & Iran \\
\hline G6 & 61-130/414-44 // 377-2 /4/ Df 21-72 // 61-130//Uvy... & Iran \\
\hline G7 & Altintash & Turkey \\
\hline G8 & Kumbet & Turkey \\
\hline G9 & Yelken & Turkey \\
\hline G10 & Selcuklu & Turkey \\
\hline G11 & Kiziltan-91 & Turkey \\
\hline G12 & Altin 40-98 & Turkey \\
\hline G13 & Yilmaz & Turkey \\
\hline G14 & Eminbey & Turkey \\
\hline G15 & Imren & Turkey \\
\hline G16 & Mirzabey-2000 & Turkey \\
\hline G17 & Received from Gene Bank SPII (Dr. Aghaee) & Iran \\
\hline G18 & Received from Gene Bank SPII (Dr. Aghaee) & Iran \\
\hline G19 & PLATA_10/6/MQUE/4/USDA573//QFN/AA... & CIMMYT \\
\hline G20 & ICAMOR-TA04-62/4/Gdr-2//(Sw Algia/Gdr1)-43/3/... & ICARDA \\
\hline
\end{tabular}




\section{جدول r- كد و مشخصات ها محيط براى ارزيابى زنوتيبٍ هاى گندم دوروم}

Table 2. Code and characteristics of the 15 environments for durum wheat genotypes assessment

\begin{tabular}{|c|c|c|c|c|c|c|c|c|c|c|}
\hline \multirow[b]{2}{*}{ Code } & \multirow[b]{2}{*}{$\begin{array}{c}\text { سال زراعى } \\
\text { Cropping season }\end{array}$} & & & & & \multirow[b]{2}{*}{$\begin{array}{c}\text { بارندگى + آبيارى } \\
\text { Rainfall + supplemental irrigation }(\mathrm{mm})\end{array}$} & \multicolumn{3}{|c|}{$\begin{array}{l}\text { los } \\
\text { Temperature }\left({ }^{\circ} \mathrm{C}\right)\end{array}$} & \multirow[b]{2}{*}{$\begin{array}{l}\text { نوع خاكs } \\
\text { Soil type }\end{array}$} \\
\hline & & \multicolumn{2}{|c|}{ 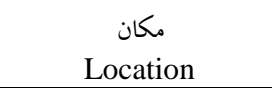 } & \multicolumn{2}{|c|}{$\begin{array}{c}\text { شرايط } \\
\text { Condition }\end{array}$} & & $\begin{array}{c}\text { Sمينه } \\
\text { Minimum }\end{array}$ & $\begin{array}{c}\text { بيشين } \\
\text { Maximum }\end{array}$ & $\begin{array}{c}\text { ميانگ } \\
\text { Average }\end{array}$ & \\
\hline KRF16 & $\mid r q 4-q \Delta 2015-16$ & Kermanshah & كرمانشاه & Rainfed & ديم & 740.3 & 3.8 & 17.4 & 11.2 & Clay-loam \\
\hline KRF17 & $1 \% 9 \Delta-992016-17$ & Kermanshah & كرمانشاه & Rainfed & ديم & 492.2 & 3.6 & 19.0 & 11.1 & Clay-loam \\
\hline KRF18 & เพ৭৭-৭ท2017-18 & Kermanshah & كرمانشاه & Rainfed & ديم & 521.2 & 6.2 & 18.8 & 12.1 & Clay-loam \\
\hline KIR16 & $\mid r q \uparrow-q \Delta 2015-16$ & Kermanshah & كرمانشاه & Irrigated & آبيارى تكميلى & $740.3+60$ & 3.8 & 17.4 & 11.2 & Clay-loam \\
\hline KIR17 & $1 \% q \Delta-৭ \$ 2016-17$ & Kermanshah & كرمانشاه & Irrigated & آبيارى تكميلى & $492.2+60$ & 3.6 & 19.0 & 11.1 & Clay-loam \\
\hline KIR18 & |r৭৭-৭ท2017-18 & Kermanshah & كرمانشاه & Irrigated & آبيارى تكميلى & $521.2+60$ & 6.2 & 18.8 & 12.1 & Clay-loam \\
\hline MRF16 & $\mid r q 4-9 \Delta 2015-16$ & Maragheh & مراغه & Rainfed & ديم & 434.7 & 1.6 & 10.3 & 5.6 & Loam \\
\hline MRF17 & |r৭১-৭৭2016-17 & Maragheh & 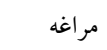 & Rainfed & ديم & 263.9 & -0.5 & 18.8 & 4.1 & Loam \\
\hline MRF18 & เพ৭ุ-৭ท 2017-18 & Maragheh & مراغه & Rainfed & ديم & 423.2 & 2.3 & 11.6 & 6.6 & Loam \\
\hline MIR16 & $\mid r q 4-9 \Delta 2015-16$ & Maragheh & 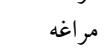 & Irrigated & آبيارى تكميلى & $434.7+60$ & 1.6 & 10.3 & 5.6 & Loam \\
\hline MIR17 & $1 \% ৭ \Delta-৭ ৭ 2016-17$ & Maragheh & 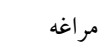 & Irrigated & آبيارى تكميلى & $263.9+60$ & -0.5 & 18.8 & 4.1 & Loam \\
\hline MIR18 & เพ৭৭-৭ท2017-18 & Maragheh & مراغه & Irrigated & آبيارى تكميلى & $423.2+60$ & 2.3 & 11.6 & 6.6 & Loam \\
\hline SRF16 & $\mid r q q-q \Delta 2015-16$ & Shirvan & شيروان & Rainfed & ديم & 334.2 & 4.1 & 18.0 & 7.6 & Clay-loam \\
\hline SRF17 & । $৭ \Delta-৭ ৭ 2016-17$ & Shirvan & شيروان & Rainfed & ديم & 137.2 & 3.1 & 17.5 & 7.4 & Clay-loam \\
\hline SRF18 & เพ৭৭-৭ท2017-18 & Shirvan & شيروان & Rainfed & ديم & 141.3 & 4.5 & 19.4 & 8.6 & Clay-loam \\
\hline
\end{tabular}


مراغه نيز ميزان بارندگى در سـالهـاى اول، دوم و سـوم

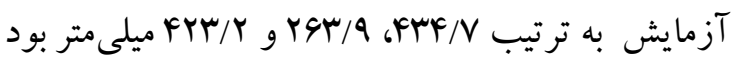

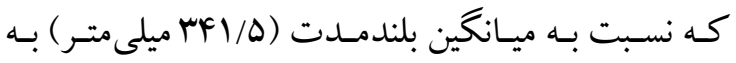

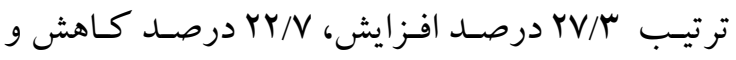


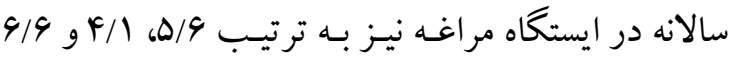

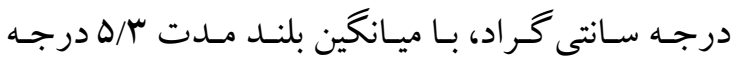

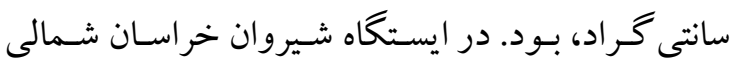

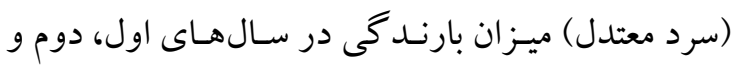

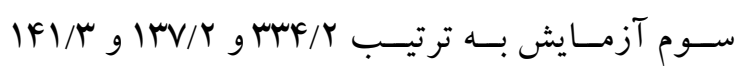

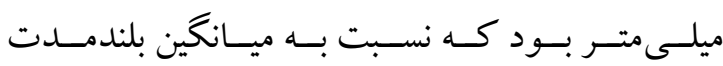

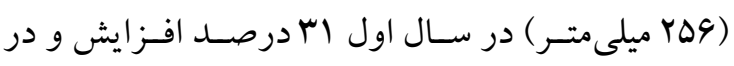

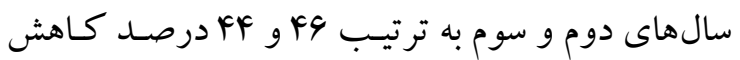

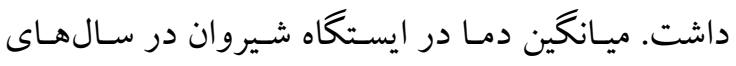

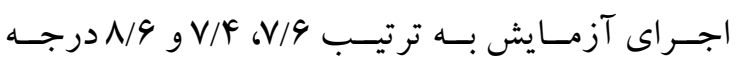

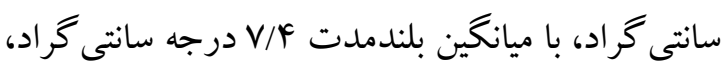

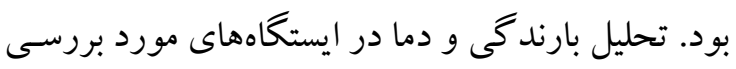

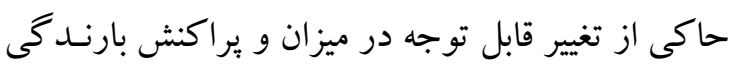

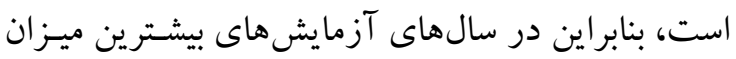

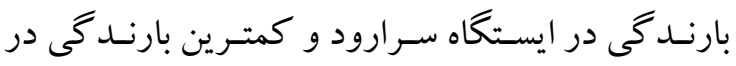

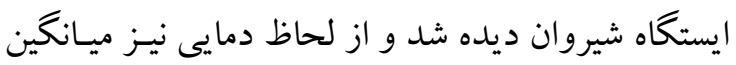

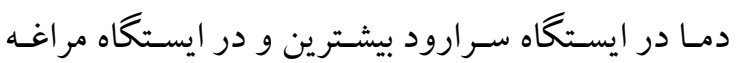

$$
\text { كمترين مقدار بود. }
$$

نتايج تجزيه واريانس مركب نشان داد كـه اخـتلاف

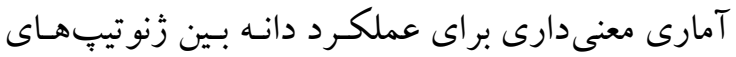

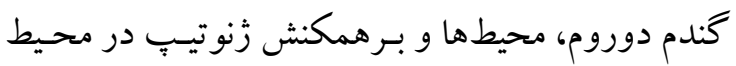

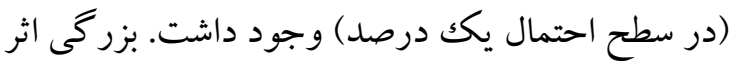

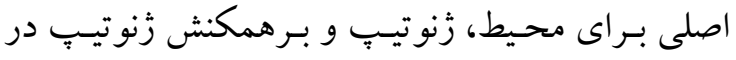

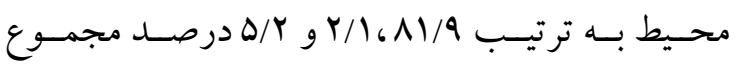
مربعات كل بود. بزركى اثر محيط نشان دهنده متفـاوت

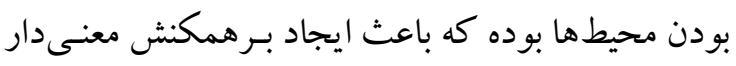

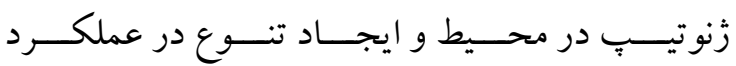

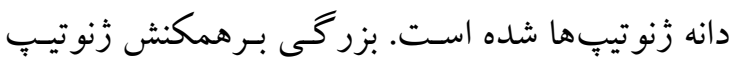

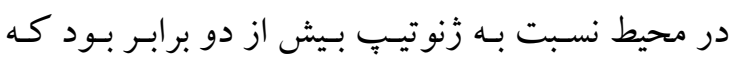

ضــريب تشــخص (Rinthus, 1973) (R²)، ضـريب تغيـــــ Francis and Kannenberg, 1978)

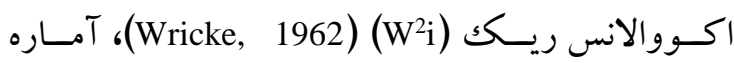
واريانس بايدارى شو كلا (Shukla, 1972)، آماره برترى

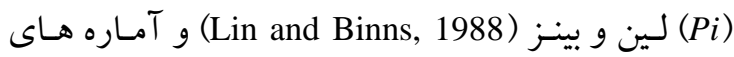

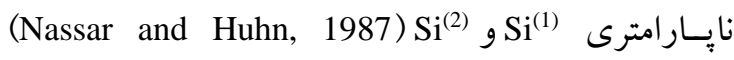

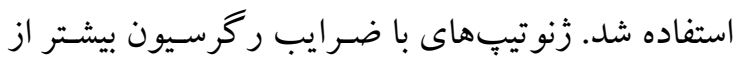

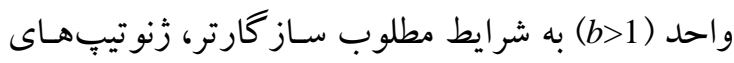

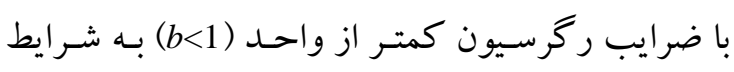

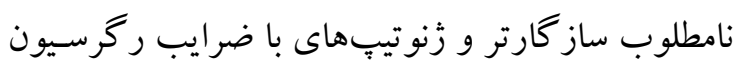

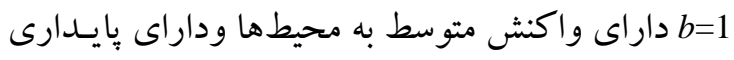
عمـومى مسىباشـند (Finlay and Wilkinson, 1963).

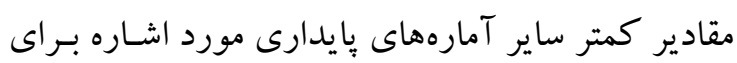

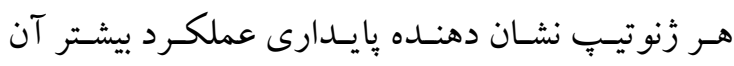

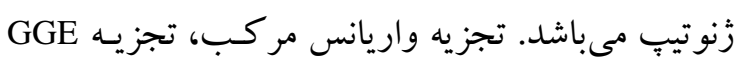

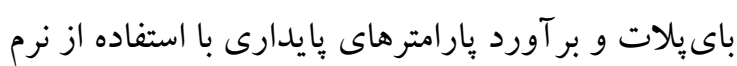

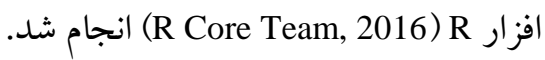

\section{نتايج و بحث}

در شر ايط ديم ميزان بارندگى و دماى هوا دو عامـل مهم در رشد و توليد محصول محسوب مىشوند. ميزان

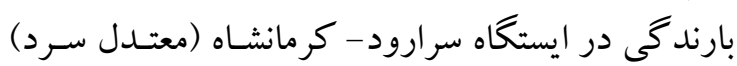
در سه سال زراعى متوالى (ه (ه)-

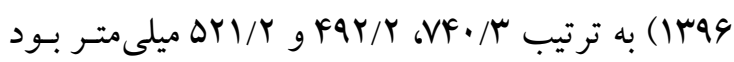

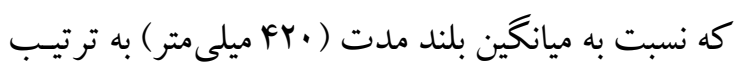

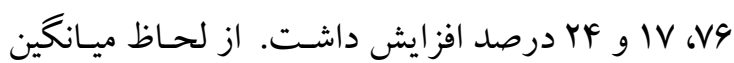

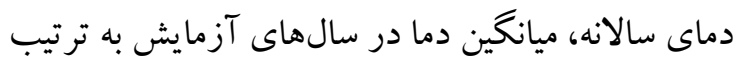

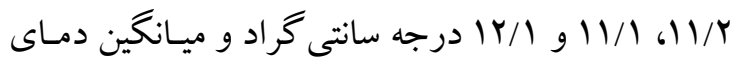

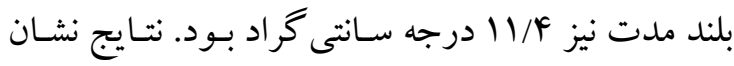

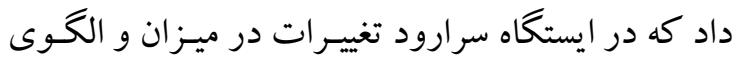

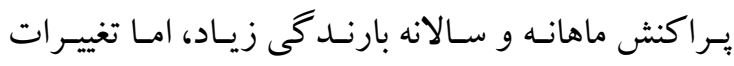

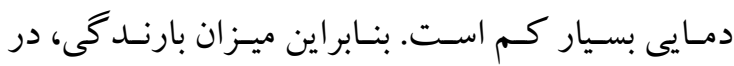

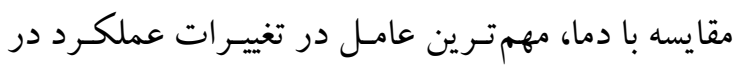

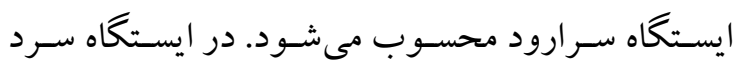




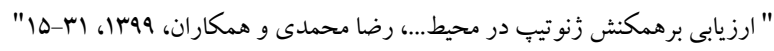

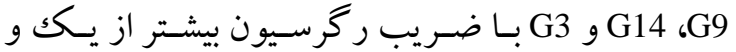

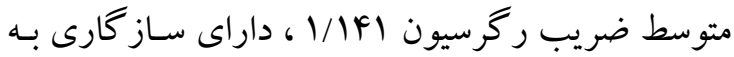

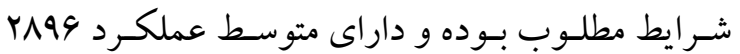

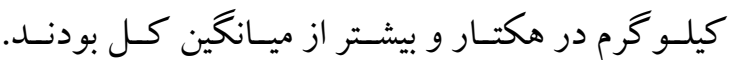

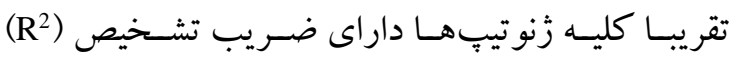

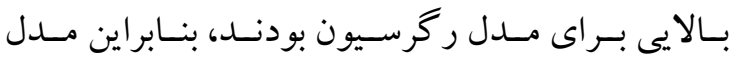

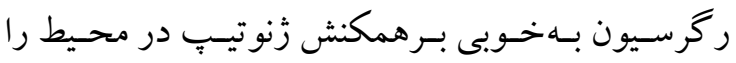
توجيـه مسىنمايسـ (Pinthus, 1973). بـر اسـاس مــدل ابرهـارت و راسـل (Eberhart and Russell, 1966) زَنوتيبهاى با كمترين واريـانس انحـر اف از ركرسيون

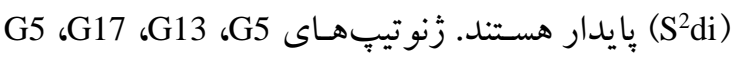

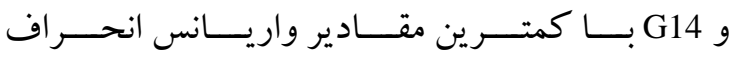

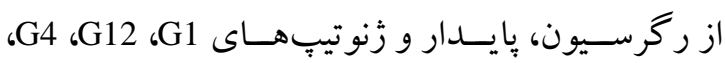

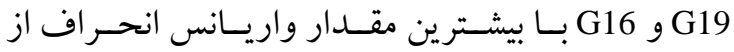

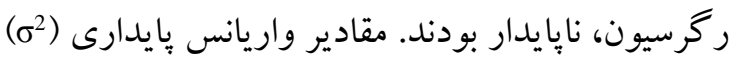

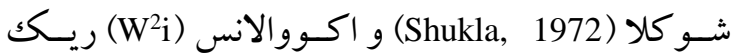
(Wricke, 1962)

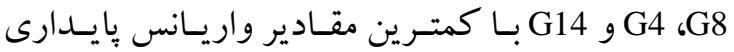
و اكـووالانس ريـكك، كمتـرين نقـش را در بـرهمكنش

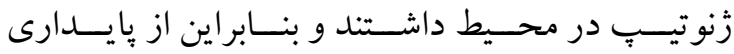
عملكرد بيشـترى نسـبت بـه سـاير زَنوتيبهـا برخـوردار

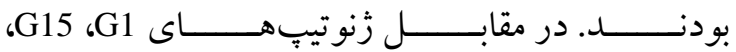
G18 و G12 دار G12 در محيط بودند. بر اساس آماره برتـرى (Pi) لـين و بينز G13 زنوتيبهـای G15 G14 (Lin and Binns, 1988)

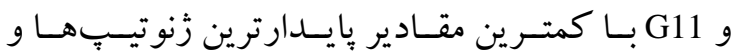
زنو تيبٍهاى G18، G19، G5 و G20 با بيشـترين مقـادير، بعنوان زَنوتيِّهاى نايايـدار شناسـايى شـدند. بـر اسـاس

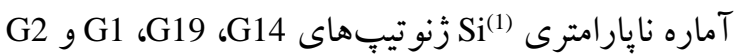

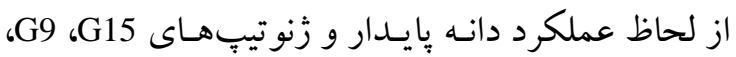

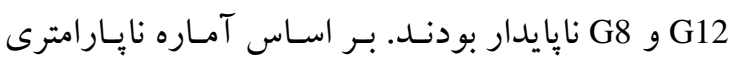

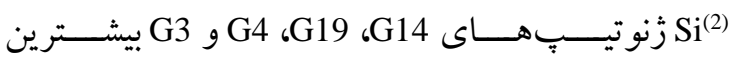

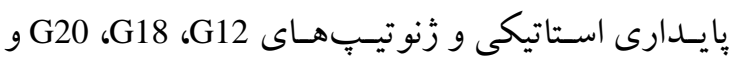
كمترين يايدارى استاتيكى را داشتند. G9

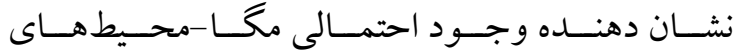
مختلف با زنو تيبهاى برتـر كـه (Mega-environments) حداكثر عملكرد را در آن مخا-محـيط دارنـد، مىباشــ

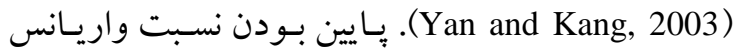
زنوتيـيَ در توجيـه واريـانس كـل نشـان دهنــده تنـوع بيشتر مولفههاى محيطى و بـرهمكنش آنها بـا زنوتيـبـ

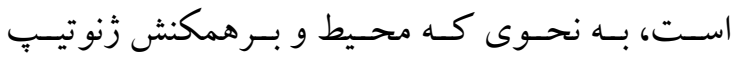
در محسيط، بيشـترين مقــدار تنـوع رادر تنـوع موجـود

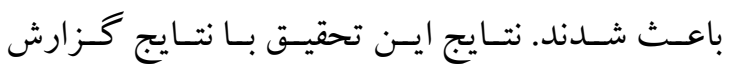
(Yan et al., 2001; Fan et al., 2007; شـــ تطـابق دارد .Rose et al., 2008) ميانگين عملكرد دانه و مقـادير آمـارههـاى بايسـارى

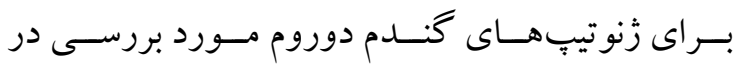

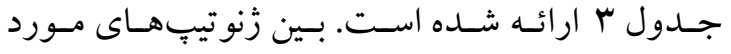
بررسـى از لحسـاظ عملكـــد دانـهـ تفــاوت معنــى دارى

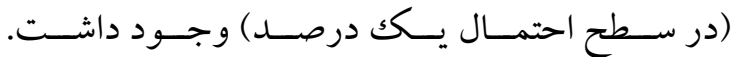

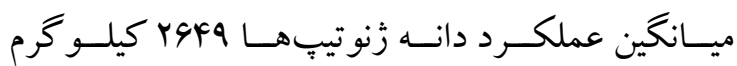
در هكتار و بيشترين عملكرد مربـوط بـه زنوتيـبـ

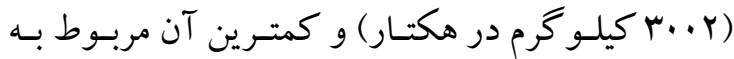

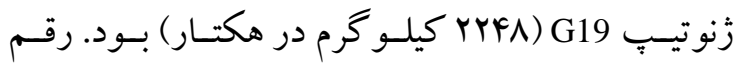

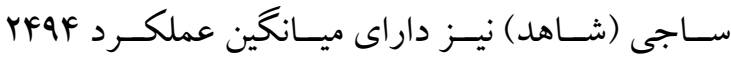
كيلـو كرم در هكتـار بـود. بر اسـاس مـــل هاى فينلـى و و ويلكينسون (Finlay and Wilkinson, 1963) و ابرهـارت و راسـل (Eberhart and Russell, 1966)، ضــــــــ ركرسـيون عملكـرد از سMV/ • (بـراى زنوتيـب

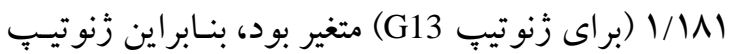
G18 دار اى بيشترين ساز گارى به محيطهـاى مطلـوب و و زَنوتيب G13 دار ای بيشترين واكنش مثبت به محيطهاى

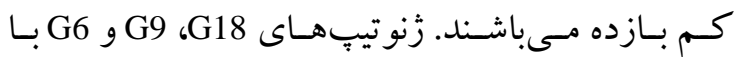

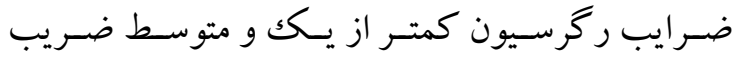
ركرسيون سYA/ • ، داراى ساز گارى به شر ايط نـامطلوب

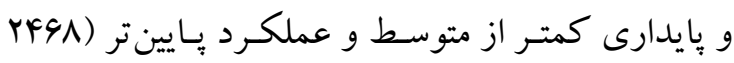

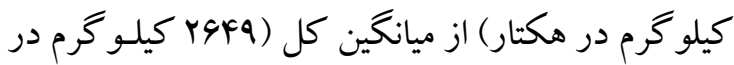
هكتار) بودند. در مقابـل زَنوتيٍ هـاى G13، G15، G11، 


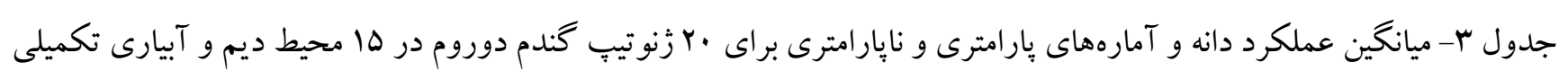

Table 3. Mean of grain yield and parametric and non-parametric stability indices for 20 durum wheat genotypes across 15 rainfed and

supplementary irrigation environments

\begin{tabular}{|c|c|c|c|c|c|c|c|c|c|c|}
\hline $\begin{array}{c}\text { Sade } \\
\text { Code }\end{array}$ & $\begin{array}{c}\text { عملكرد دانه } \\
\text { Grain yield }\end{array}$ & $\begin{array}{c}\text { ضريب تغييرات } \\
\text { Coefficient of } \\
\text { variation } \\
\end{array}$ & $\begin{array}{c}\text { ضريب ركرسيون } \\
\text { Coefficient of } \\
\text { regression } \\
\end{array}$ & $\begin{array}{c}\text { واريانس انحراف از ركرسيون } \\
\text { Variance in regression } \\
\text { deviation }\end{array}$ & $\begin{array}{c}\text { ضريب تشخيص } \\
\text { Coefficient of } \\
\text { determination } \\
\end{array}$ & $\begin{array}{c}\text { واريانس يايدارى } \\
\text { Stability } \\
\text { variance } \\
\end{array}$ & $\begin{array}{c}\text { اكووالانس ريك } \\
\text { Wricke's } \\
\text { ecovalence } \\
\end{array}$ & $\begin{array}{c}\text { آماره برترى } \\
\text { Superiority } \\
\text { index }\end{array}$ & $\begin{array}{c}\mathrm{Si}^{(1)} \mathrm{T} \\
\mathrm{Si}^{(1)} \text { non-parametric } \\
\text { statistic }\end{array}$ & $\begin{array}{c}\mathrm{Si}^{(2)} \mathbf{T} \mathrm{T} \\
\mathrm{Si}^{(2)} \text { non-parametri } \\
\text { statistic }\end{array}$ \\
\hline G1 & 2494 & 61.6 & 1.036 & 159325 & 0.9031 & 250176 & 3245800 & 560216 & 0.64 & 30.4 \\
\hline G2 & 2643 & 48.2 & 0.867 & 49874 & 0.9215 & 173433 & 2278832 & 448210 & 0.64 & 28.1 \\
\hline G3 & 2918 & 53.5 & 1.081 & 33307 & 0.954 & 131839 & 1754756 & 185191 & 0.74 & 16.6 \\
\hline G4 & 2512 & 51.3 & 0.903 & 46518 & 0.977 & 55759 & 796141 & 494054 & 0.69 & 16.2 \\
\hline G5 & 2389 & 59.4 & 0.987 & 1906 & 0.9606 & 81416 & 1119426 & 599047 & 0.74 & 22.5 \\
\hline G6 & 2454 & 50.7 & 0.870 & 43290 & 0.9734 & 75781 & 1048420 & 548359 & 0.77 & 19.4 \\
\hline G7 & 2604 & 52.9 & 0.959 & 11270 & 0.9627 & 75077 & 1039546 & 404743 & 0.92 & 27.8 \\
\hline G8 & 2738 & 53.3 & 1.023 & 35945 & 0.9775 & 47019 & 686020 & 270299 & 0.94 & 25.7 \\
\hline G9 & 2726 & 58.9 & 1.112 & 41682 & 0.9535 & 153740 & 2030700 & 309061 & 0.98 & 35.0 \\
\hline G10 & 2727 & 52.5 & 1.009 & 59337 & 0.9872 & 21930 & 369901 & 279944 & 0.72 & 17.9 \\
\hline G11 & 2876 & 56.6 & 1.143 & 32014 & 0.9805 & 94959 & 1290060 & 173584 & 0.74 & 20.5 \\
\hline G12 & 2776 & 51.6 & 0.967 & 121622 & 0.9055 & 210956 & 2751626 & 309566 & 0.94 & 44.0 \\
\hline G13 & 2917 & 58.0 & 1.181 & 6498 & 0.9695 & 162393 & 2139732 & 145949 & 0.78 & 29.1 \\
\hline G14 & 2960 & 53.1 & 1.106 & 49108 & 0.9855 & 56937 & 810982 & 122577 & 0.47 & 9.5 \\
\hline G15 & 3002 & 56.3 & 1.165 & 76368 & 0.9467 & 222182 & 2893076 & 138321 & 1.00 & 33.2 \\
\hline G16 & 2720 & 55.1 & 1.021 & 102144 & 0.9217 & 189309 & 2478878 & 331157 & 0.70 & 28.1 \\
\hline G17 & 2505 & 54.2 & 0.939 & 7868 & 0.952 & 99320 & 1345007 & 480402 & 0.77 & 29.5 \\
\hline G18 & 2307 & 46.1 & 0.733 & 18756 & 0.9436 & 221524 & 2884778 & 822244 & 0.87 & 41.0 \\
\hline G19 & 2248 & 64.3 & 0.976 & 120642 & 0.9075 & 208727 & 2723534 & 791693 & 0.59 & 14.6 \\
\hline $\mathrm{G} 20$ & 2454 & 55.0 & 0.925 & 44318 & 0.9329 & 141215 & 1872888 & 586844 & 0.83 & 37.9 \\
\hline
\end{tabular}




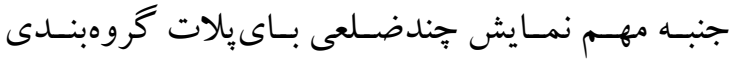

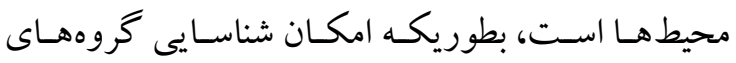
محيطـى معنــى دار در يـك ناحيـه (منطقـه) را فــراهم مىنمايسـد. بـر ايسن اسـاس محيطهـا بـه جهـار خـروه و

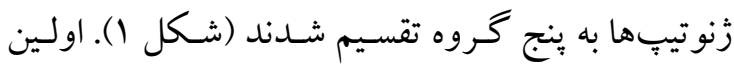

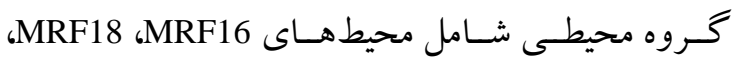

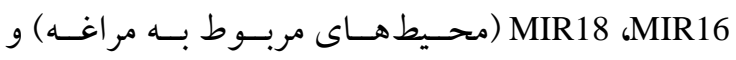
KIR18 و KRF16 (محيط هاى مربوط به كرمانشـاه) بـود

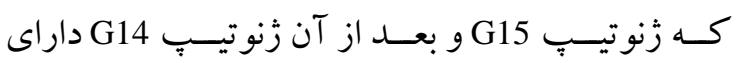
بيشترين عملكرد در اين گروه محيطى بودند. گروه دوم

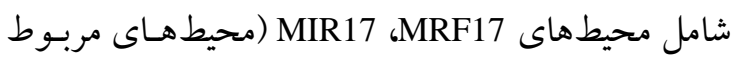

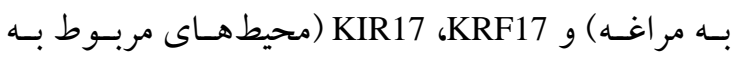
كرمانشـاه) و SRF16 و SRF18 (محيطهـاى مربسوط بـه شيروان) بود كه زَنو تيب G3 داراى بيشترين عملكـرد در

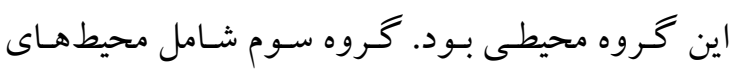

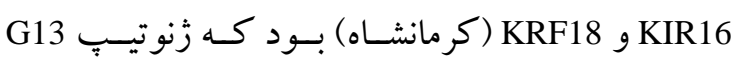
داراى بيشترين عملكرد در اين گروه محيطى بود. گروه جهارم محيطى شامل محيط SRF17 (محيط مربـوط بـه شيروان) بود كه زَنوتيـب G18 دار ایى بيشـترين عملكـرد

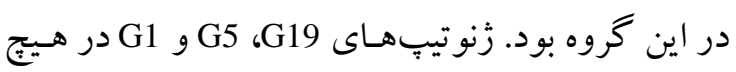
كدام از محيطها برتر نبودند. نتايج حاصل از گروهبندى
يكى از جنبـهاى GGE بـاى يلات، تجزيسه الخـوى

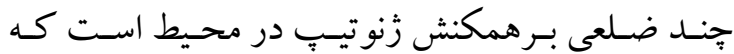
بهترين روش براى مشاهده الخوهاى برهمكنش زَنوتيـبٍ

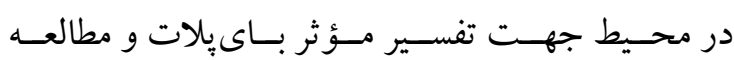

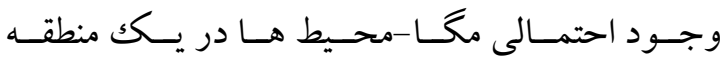

(Gauch and Zobel, 1997; Yan et al., 2000; مىباشــ Yan and Kang, 2003) در شكل ا، نمايش جند ضلعى (ر)

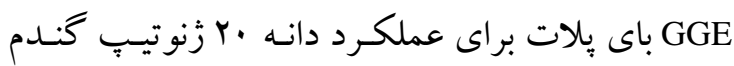
دوروم در ها محيط ديسم و آبيـارى تكميلى نشـان داده شده است. در اين شكل زنوتيڤ هايى كه بيشترين فاصله را از مر كز باى بلات دارند، توسط خطسوط مسـقيمى بـه هم متصل شدهاند و بقيه زَنوتيڤها در درون جندضـلعى قرار دارند. زنوتيٍٍايى كه رئوس جندضلعى را تشكيل مى دهند شامل G15، G3، G13، G18 و G19 هستند. اين زَنوتيِها از لحاظ عملكرد دانه بهترين و يا ضعيفترين

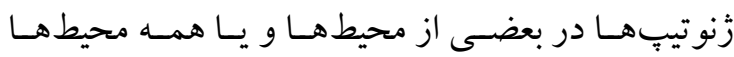
هستند، زيرا داراى بيشترين فاصـله از مركـز بـاى بـلات

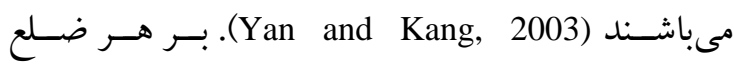
جندضلعى يكك عمود از مر كز بـاى يلات رسـم مى شـود كه باى يلات را به جند بخش تقسيم مى كند كه محيطها

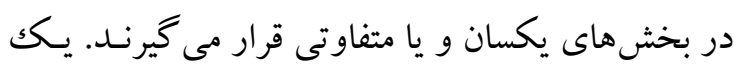

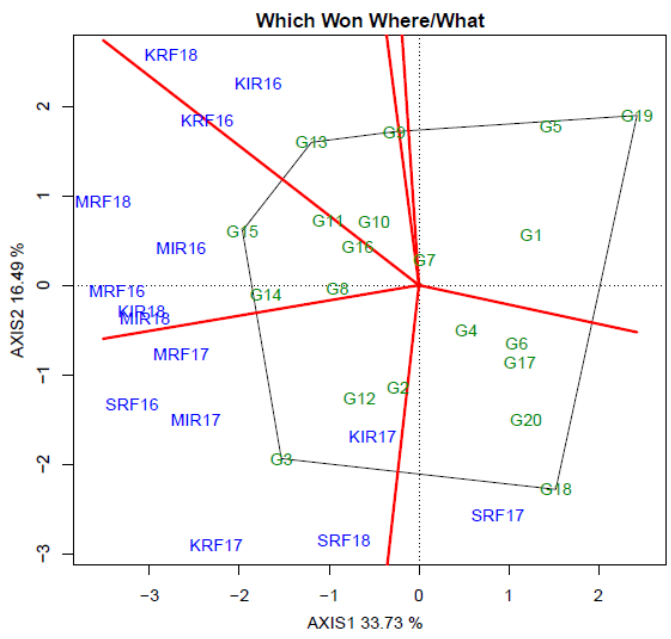

شكل ا-نمايش كرافيكى GGE باى يلات عملكرد دانه ·r زَنوتيب گندم دوروم در ها محيط ديم و آبيارى تكميلى

Fig. 1. GGE biplot for grain yield of 20 durum wheat genotypes across 15 rainfed and supplementary irrigation environments 
خطى كه بر خـط ATC عمـود و از مركـز بـاىيلات

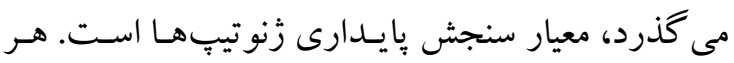
جه زَنو تيبٍ ها از اين خط فاصله بيشترى داشته باشند، در بـرهمكنش نقـش بيشـترى داشـته و بايسـارى كمتـرى خو اهند داشـت. بـر ايـن اسـاس زنوتيـي G14 از لحساظ تر كيب بايدارى و عملكرد، بهترين زنوتيب و بعد از آن

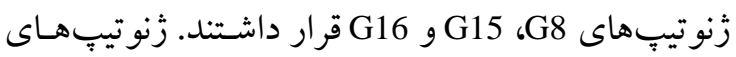

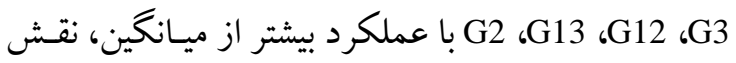

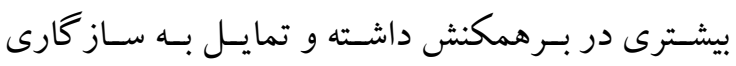
خصوصى داشتند. زُنوتيبهاى G20، G18، G5 و G19 با

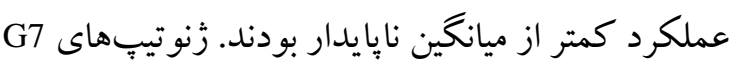
و G9 با عملكـرد در حـــ متوسـط بـه ترتيـب بيشـترين و كمترين بايدارى عملكرد را در محيطهاى مورد بررسى داشتند.

در نمايش باى يلات (شكل ب)، كسينوس زاويـه بـين دو بردار محيطى (خطوطى كه نشانكرهاى محيطى را بـه

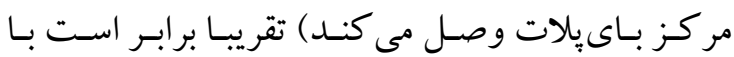
همبستكى بين دو محيط، كه هر جه زاويه بـين دو بـردار

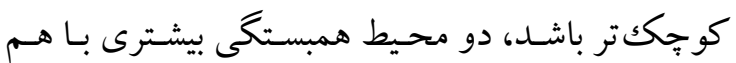
دارند (Yan and Kang, 2003). بر اين اسـاس كروههـاى مهري

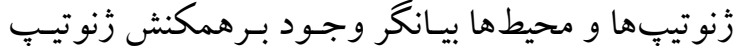
در محيط است، بطوريكه رتبه زنوتيبهـا در محيطهـاى مختلف متفاوت و كاهى عكس هم مسىباشــ كـه نشـان دهنده برهمكنش كر اساورى در برنامه بـهنـز ادى گنـدم دوروم در مناطق ديم معتدل و سرد كشور مىباشد. عدم امكان قراركرفتن محيطهاى مربسوط بـه يـك مكـان در يكك كروه نيز نشـان دهنـده وجـود بـرهمكنش سـال در

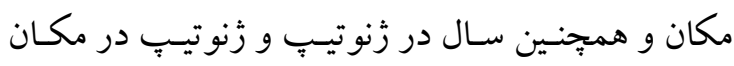
مى.باشد.

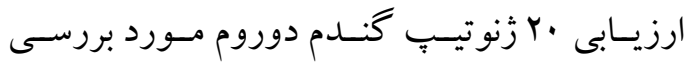
بر اساس عملكـرد دانسه و ميززان يايسـارى در ها محسيط در شـكل ب ارائسه شــده اسـتـ. خطسى كـهـ از مركـز بـاى بلات مى كـــرد و از نقطـه مطلـوب (كـه نماينــده متوسط ضسرايب دو مولفهه اول بـرهمكنش (PC1, PC2)

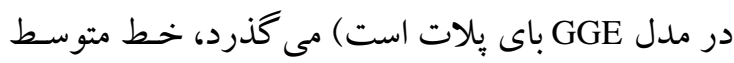
عملكرد محيطى (Average Tester Coordinate; ATC) ناميـده مىشـود (Yan and Kang, 2003). زَنوتيب هـايى

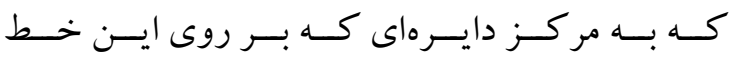

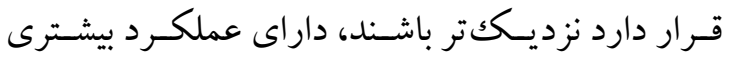
هستند.

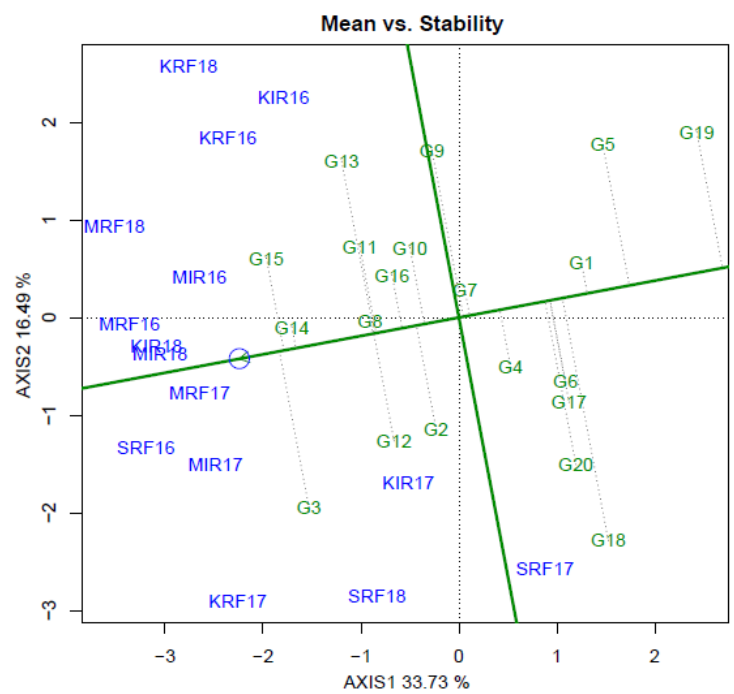

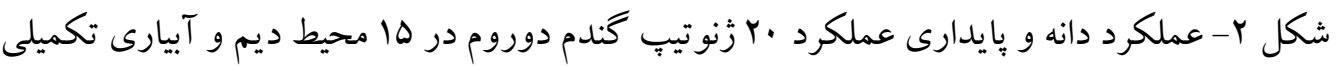

Fig. 2. Grain yield and yield stability of 20 durum wheat genotypes across 15 rainfed and supplementary irrigation environments 
آب و هوايى متنوع و برهمكنش زنوتيسب در سـال قابـل

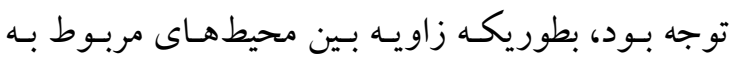

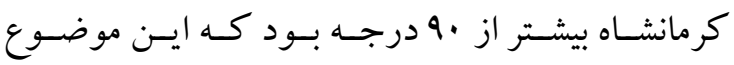

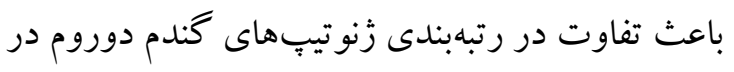
سالهاى مورد بررسى شـد. يـك محيط مطلموب بايسـ

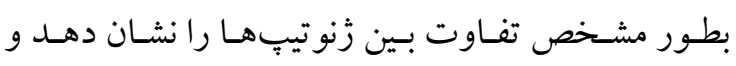

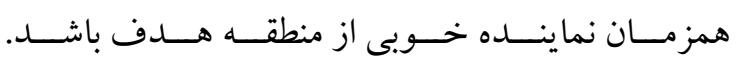

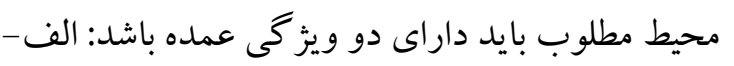

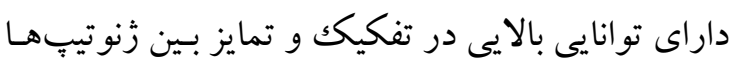

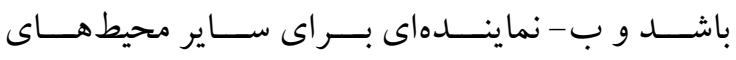
مـورد آزمـايش باشــ (Yan and Kang, 2003). ايسن

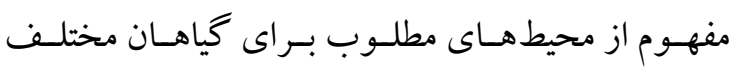

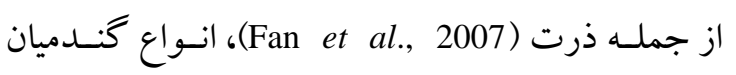
(Dobins et al., 2007) مورد استفاده قرار كرفته است.

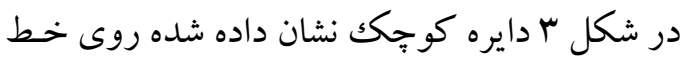
ATC

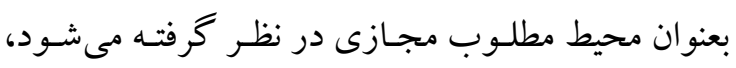

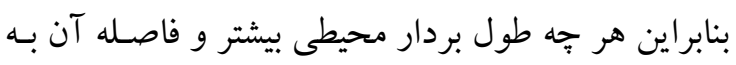

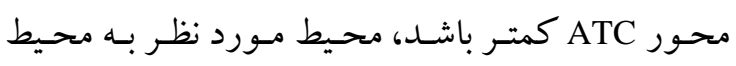

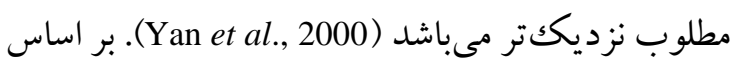

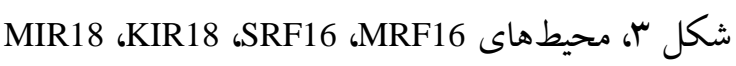

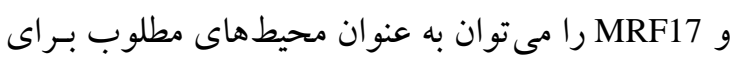

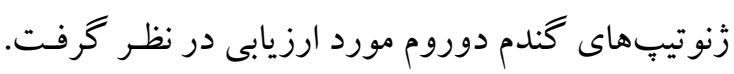

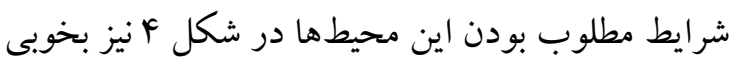

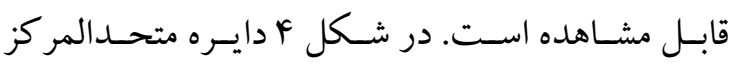

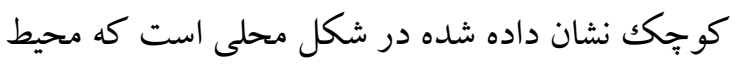
مطلـوب قـرار دارد و هـر جـهـ محيطسى بــه ايسن دايسره

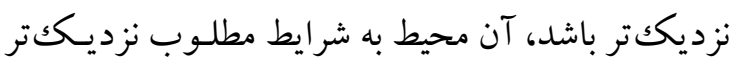

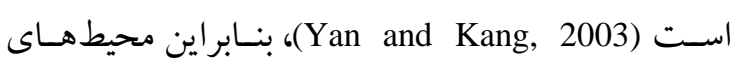
SMR17 MIR18،KIR18، SRF16 ،MRF16 نزديكك به دايره متحدالمركز هستند، نماينده محيطهـاى

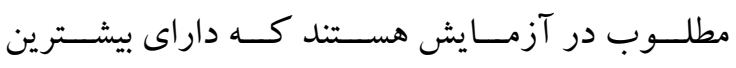
قدرت تمايز و نمايندگى مى باشند. هر جـهـ طـول بـردار
محيطى در يك منطقه كـه گروهـى از مـواد زنتيكى در

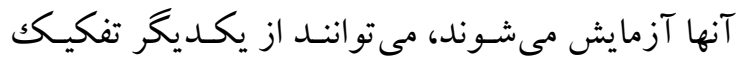

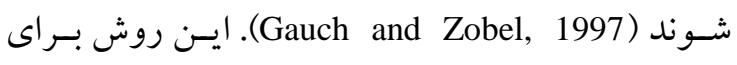
تفكيك محيطهاى مشابه از محيطهـاى غيـر مشـابه قبلا

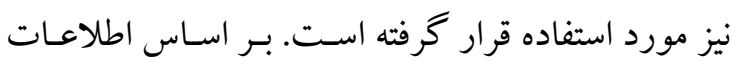
شكل ب بيشترين تشابهات بين محيط هاى مورد آزمايش

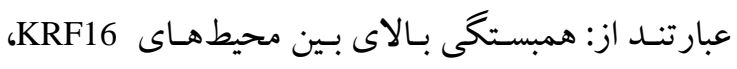

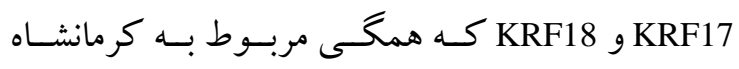

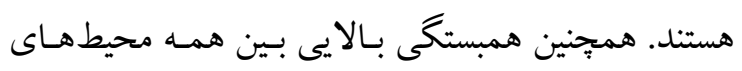

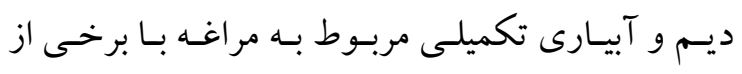

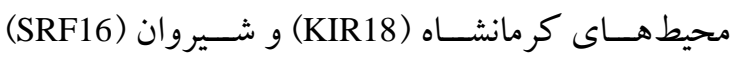

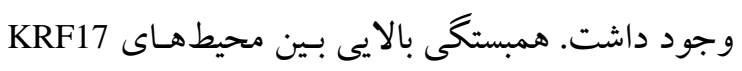

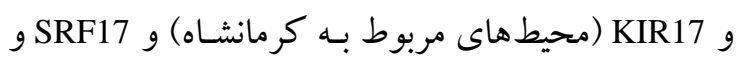

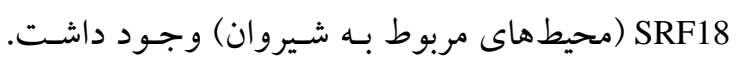
زاويه بين بردارهاى محيطى مربوط بـه مراغـه و شـيروان

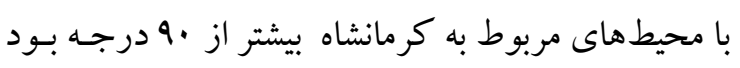

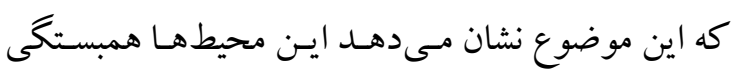

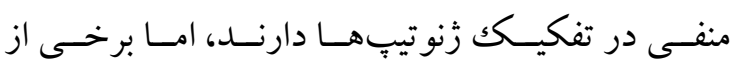

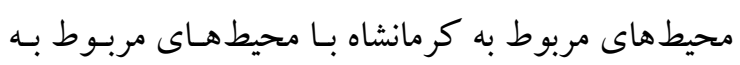

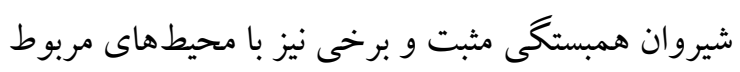
به مر اغه همبستخى مثبت داشتند.

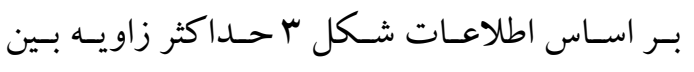

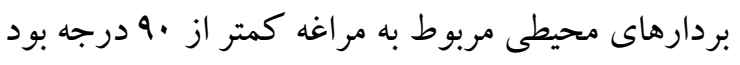

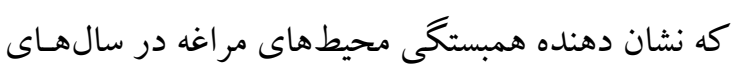

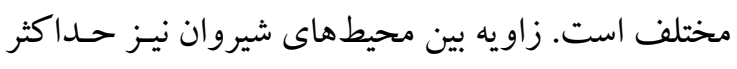

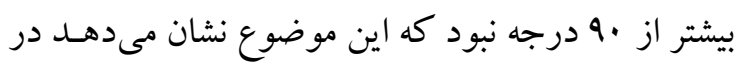

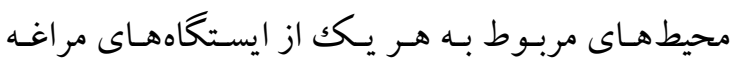

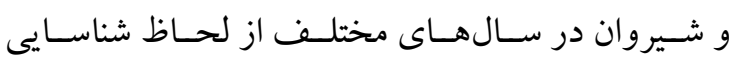

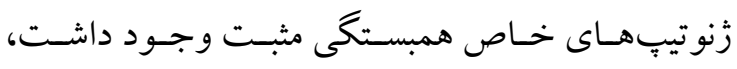

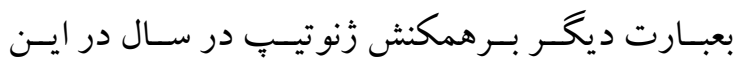

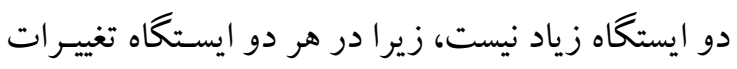

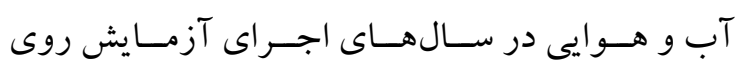

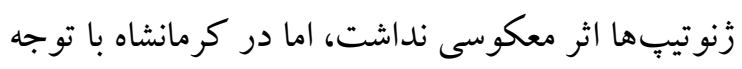

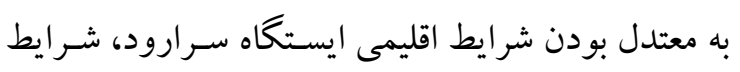




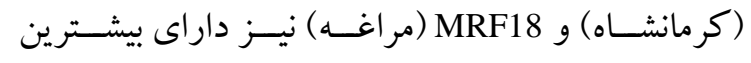

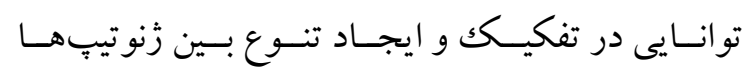

بودند، اما نماينده خوبى براى ساير محيطها نبودنسـ. بـر

اساس شكل ب محيطهاى مربوط به كرمانشاه و شـيروان

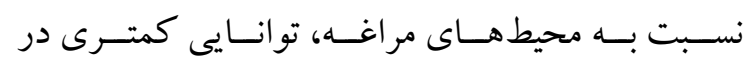

محيطى كوجـكـ تر باشــد، آن محسيط توانـايى كمتـرى

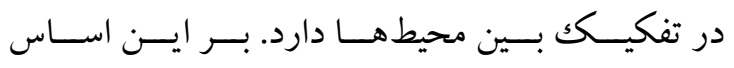

محسط KIR17 (محــيط آبيـارى تكميلـى كرمانشـاه) داراى كمترين توانـايى در تفكيكك و ايجـاد تنـوع بـين

زرنو تيبّهـــا اســت. محيطهـــاى KRF17 و KRF18

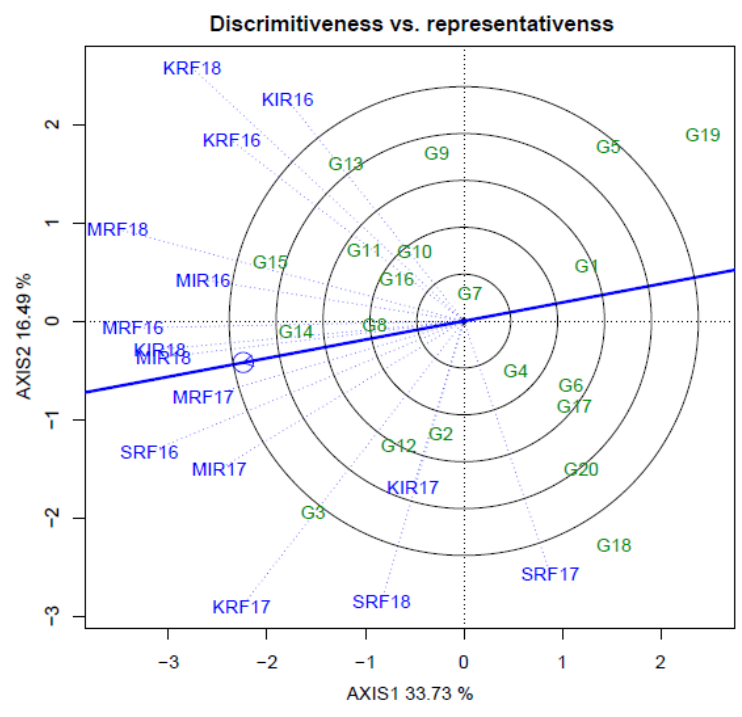

شكل ب- ارزيابى محيطها از نظر "قدرت تفكيك در مقابل نمايندكى " آنها براى ارزيابى زنوتيبٍهاى كندم دوروم

Fig. 3. Evaluation of test environments for "Discriminating power vs. Representativeness" for evaluation of durum wheat genotypes

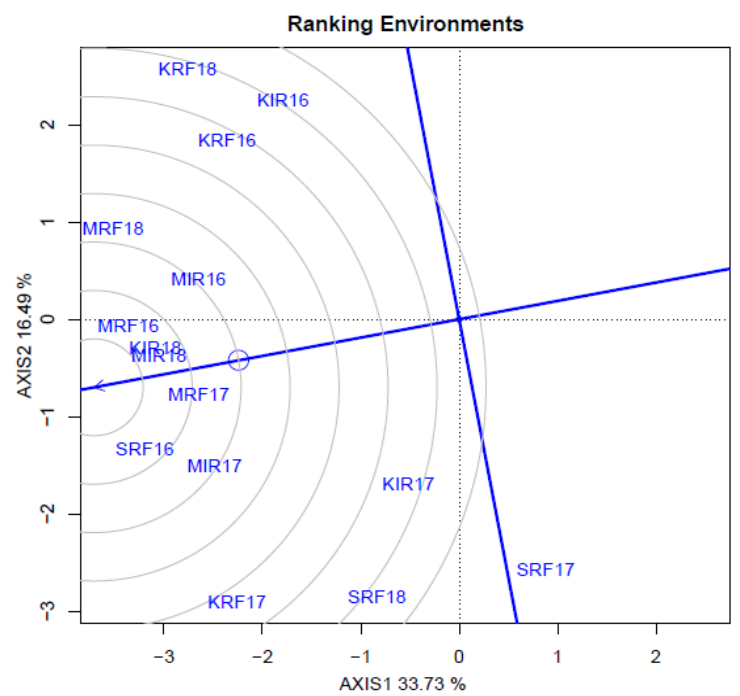

شكل F - ارزيابى محيطها نسبت به محيط مطلوب در مدل GGE باى يلات براى ارزيابى زنوتيٍ هاى گندم دوروم

Fig. 4. GGE biplot showing evaluation of test environments in compared to an ideal environment for evaluation of durum wheat genotypes 


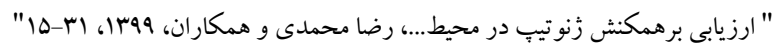

ميـانخين زنو تيبهـاى بـا عملكـــد بـالا و داراى حـداقل

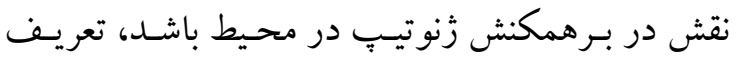
شده است (بهصورتى كه در شكل ه بصورت يك دايره

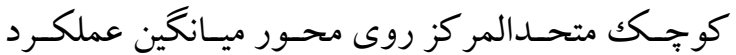

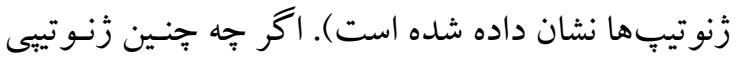
در عمل وجود ندارد، امـا مى تو انـــ بعنـوان يـك مرجـع

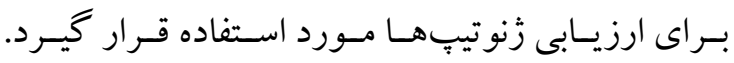
زنوتيبى مطلوب در نظر كرفته مىشود كه به ايسن مرجـع نزديككتر باشد. بـر ايسن اسـاس زنوتيبهــــ G14، G8،

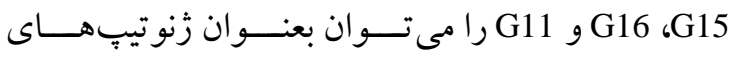
مطلــوب در آزمــايش حاضـر كــه داراى ميــانگين و يايدارى عملكرد بالايى بودند، در نظر كرفت.
تفكيكك و نمايندكى سـاير محيطهـا داشـتند. دليـل ايـن

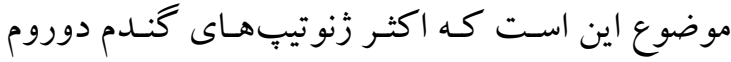
مورد بررسى در اين تحقيسق زمسـتانه بـوده و سـاز گارى بهترى نسـبت بـه محسيطهـاى سـرد مراغـه داشـتند. ايسن شرايط امكان شناسايى لاين هاى اميد بخـش زمسـتانه در

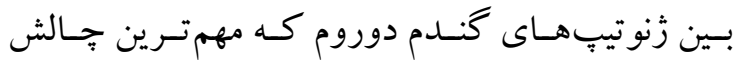
فراروى توسعه اين محصول در مناطق سـرد مسىباشـد را

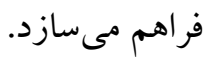
يكك زنوتيٍٍ مطلـوبِ بايسـ داراى بيشـترين ميـانكين عملكرد در محيط هاى مـورد مطالعسه و عملكـرد يايسـار نسـبت بـه شـرايط محيطى متغيـر باشـد. جنسين زنـوتيبى

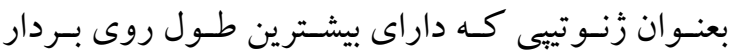

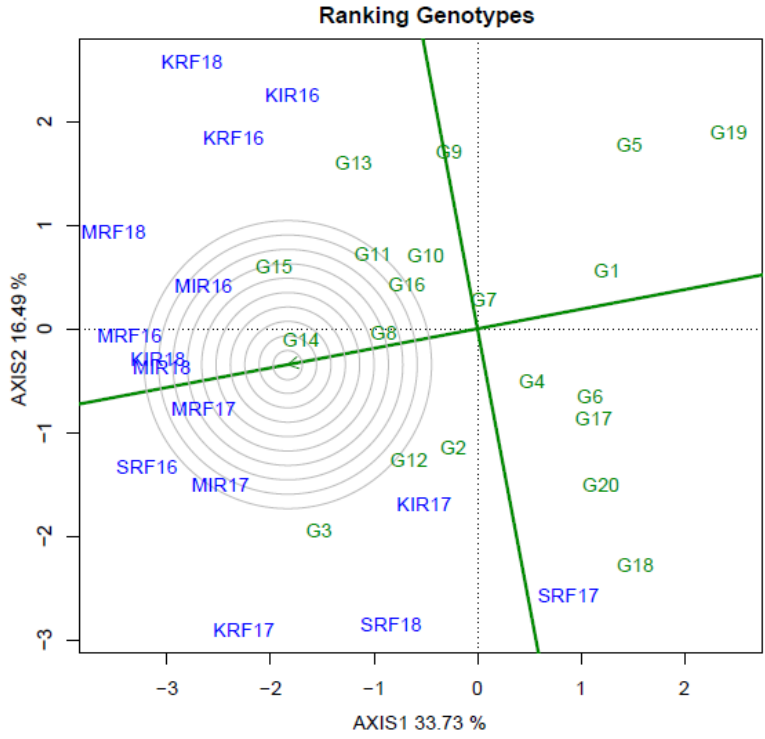

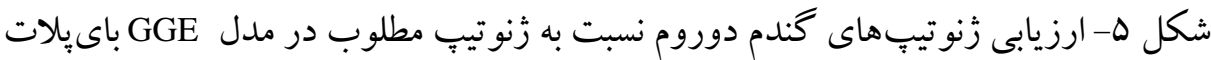

Fig. 5. GGE biplot showing evaluation of durum wheat genotypes compared to an ideal genotype

لاين هاى زمستانه بـراى توسعه كشـت كنـدم دوروم در مناطق ديم سرد مي باشد. بـا توجـهـ بـهـ وجـود عـدم رقـم

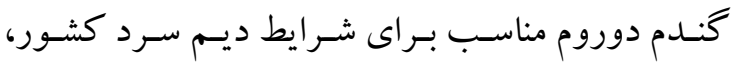
بهـرهبـردارى از ايسن لايـنهـا مسى توانـد مشـكل عسدم دسترسى به رقم مناسب كندم دوروم بـراى منـاطق ديسم سردسير كشور را مرتفع نمايد.
مقايسـه سـاز كارى لايسنهـاى زمسـتانه G14 و G15 نسـبت بـه شـاهد آزمـايش (G1) در محيطهـاى سـرد و معتدل سرد به ترتيب در شكل هاى 9 و V نشان داده شده اسـت. همـانطور كـه در شـكل نشـان داده شـده اسـت، لاينهاى با تيب زمستانه ساز كارى بيشترى به محيط هاى سرد دارند و اين موضوع نشـان دهنــده اهميـت انتخـاب 


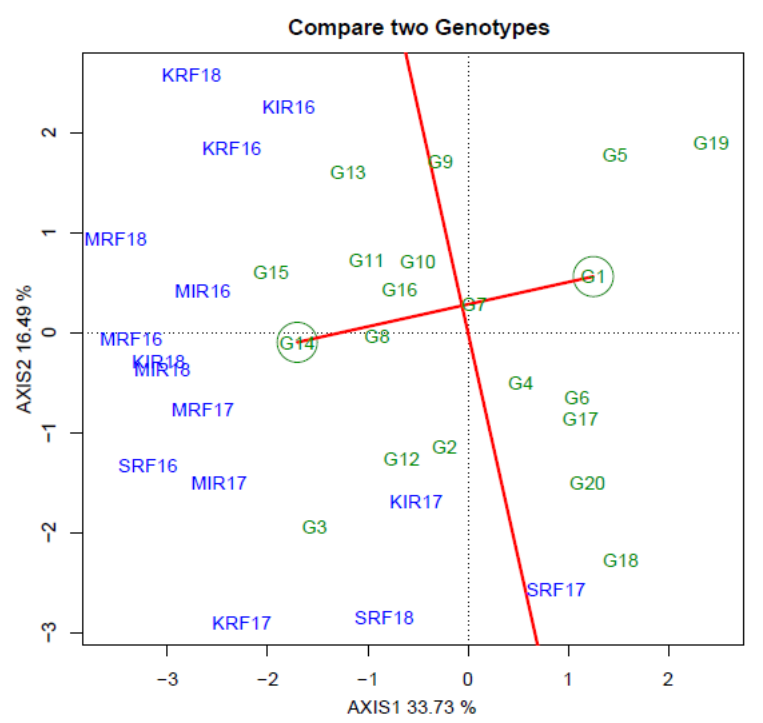

شكل 9- مقايسه ساز گارى لاين اميدبخش G14 با شاهد (G1) گندم دوروم در محيطهاى سرد و معتدل سرد

Fig. 6. Comparison of promising line G14 with the check (G1) of durum wheat in cold and moderate cold environments

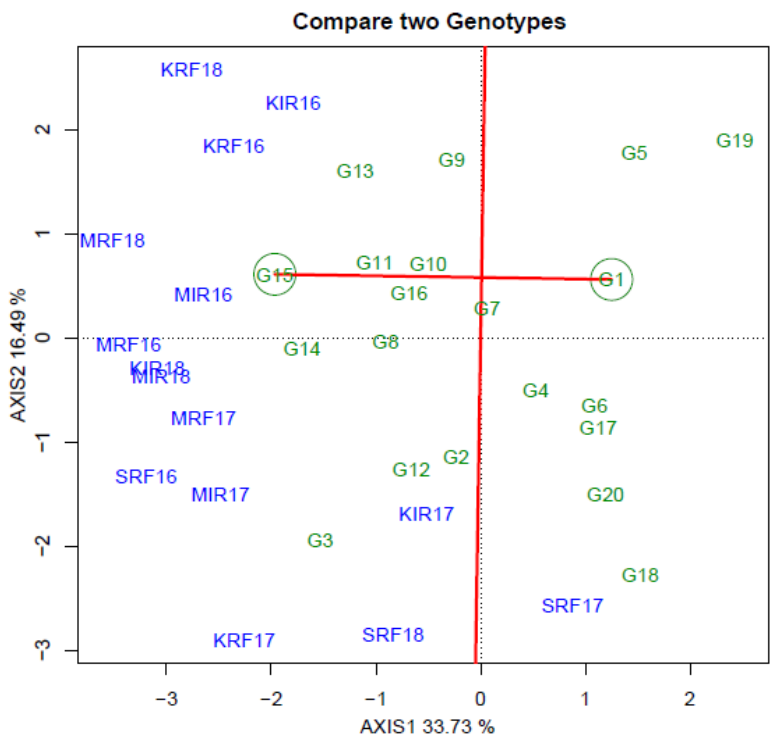

شكل V- مقايسه ساز گارى لاين اميدبخش G15 با شاهد (G1) گندم دوروم در محيطهاى سرد و معتدل سرد

Fig. 7. Comparison of promising line G15 with the check (G1) of durum wheat in cold and moderate cold environments

داشته و امكان انتخاب لاينهـاى بـا بِتانسـيل و پِيــارى

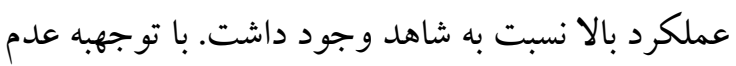
وجود رقم مناسب براى شرايط ديسم سردسير در برنامـهـ

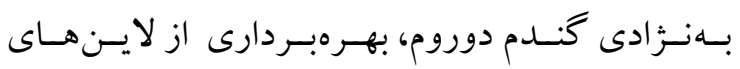

\section{نتيجه كيرى}

نتايج ايـن تحقيـق نشـان داد كـه تنـوع زيـادى بــاى ديرى

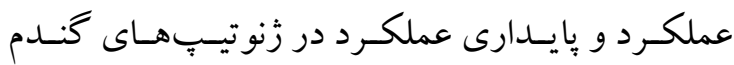

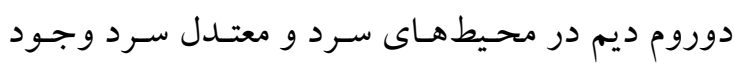




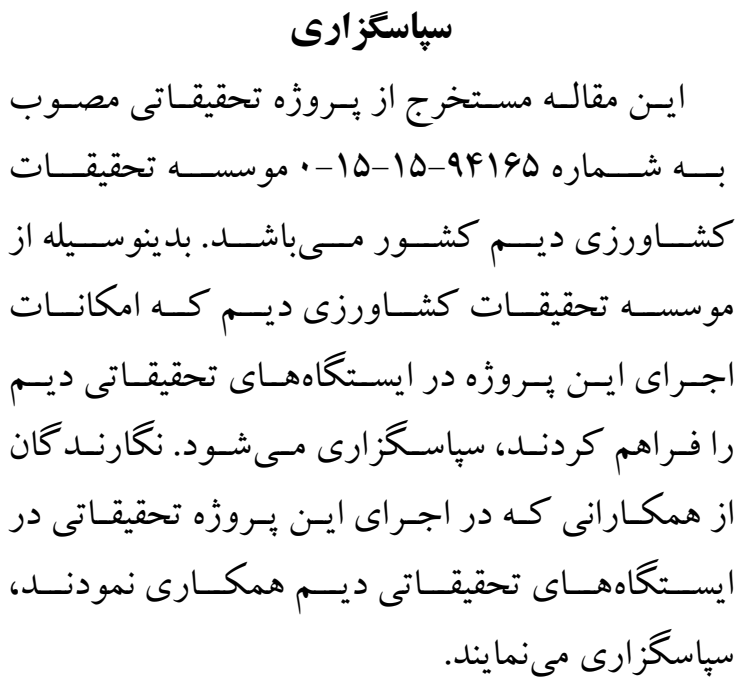

\section{References}

Able, J., and S. Atienza. 2014. Durum wheat for the future: Challenges, research, and prospects in the $21 \mathrm{st}$ century. Crop Pasture Sci. 65: 1-124.

Balalić, I., M. Zorić, G. Branković, S. Terzić and J. Crnobarac. 2012. Interpretation of hybrid× sowing date interaction for oil content and oil yield in sunflower. Field Crops Res. 137: 70-77.

Dimitrios, B., G. Christos, R. Jesus and B. Eva. 2008. Separation of cotton cultivar testing sites based on representativeness and discriminating ability using GGE Biplots. Agron. J. 100: 1230-1236.

Eberhart, S. A. and W. A. Russell. 1966. Stability parameters for comparing varieties. Crop Sci. 6: 36-40.

Fan, X. M., M. S. Kang, H. Chen, Y. Zhang, J. Tan and C. Xu. 2007. Yield stability of maize hybrids evaluated in multi-environment trials in Yunnan, China. Agron. J. 99: 220-228.

Finlay, K. W. and G. N. Wilkinson. 1963. The analysis of adaptation in a plant breeding program. Aust. J. Agric. Res. 14: 742-754.

Francis, T. R. and L. W. Kannenberg. 1978. Yield stability studied in short-season maize. I. A descriptive method for grouping genotypes. Can. J. Plant Sci. 58: 1029-1034.

Gabriel, K. R. 1971. The biplot graphic display of matrices with application to principal component analysis. Biometrika 58: 453-467.

Gauch, H. G. and R. W. Zobel. 1997. Identifying mega-environments and targeting genotypes. Crop Sci. 37: 311-326.

Lin, C. S. and M. R. Binns. 1988. A method for analyzing cultivar x location $x$ year experiments: a new stability parameter. Theor. Appl. Genet. 76: 425-430.

Nachit, M. M., M. Baum, E. Poreciddu, P. Monneveux and E. Picard. 1998. SEWANA (South Europe, West Asia and North Africa) Durum Research Network. Proceeding of the SEWANA Durum Network Workshop, 20-23 March 1995. ICARDA, Aleppo, Syria.

Moslemi, M., M. Roustaii and V. Rashidi. 2012. Evaluation of grain yield and yield components in bread 


$$
\text { "نشريه علوم زراعى ايران"، جلد بيست و دوم، شماره ا، بهار }
$$

wheat genotypes under different moisture regimes. Seed Plant Improv. J. 28(4): 611-630. (In Persian with English abstract).

Nassar, R. and M. Huhn. 1987. Studies on estimation of phenotypic stability: Tests of significance for nonparametric measures of phenotypic stability. Biometrics 43: 45-53.

Perkins, J. M. and J. L. Jinks. 1968. Environment and genotype-environmental components of variability. Heredity 23: 339-3256.

Plaisted, R. L. and L. C. Peterson. 1959. A technique for evaluating the ability of selections to yield consistently in different locations or seasons. Am. Pot. J. 36: 381-385.

Pinthus, J. M. 1973. Estimate of genotype value: a proposed method. Euphytica, 22: 121-123.

R Core Team. 2016. R: A language and environment for statistical computing. R Foundation for Statistical Computing, Vienna, Austria.

Rakshit, S., K. N. Ganapathy, S. S. Gomashe, A. Rathore, R. B. Ghorade, M. V. Nagesh-Kumar, K. Ganesmurthy, S. K. Jain, M. Y. Kamtar, J. S. Sachan, S. S. Ambekar, B. R. Ranwa, D. G. Kanawade, M. Balusamy, D. Kadam, A. Sarkar, V. A. Tonapi and J. V. Patil. 2012. GGE biplot analysis to evaluate genotype, environment and their interactions in sorghum multi-location data. Euphytica, 85: 465-479.

Sharma, R. C., A. I. Morgounov, H. J. Braun, B. Akin, M. Keser, D. Bedoshvili, A. Bagci, C. Martius and M. van Ginkel. 2010. Identifying high yielding stable winter wheat genotypes for irrigated environments in Central and West Asia. Euphytica, 171: 53-64.

Robins, J. G., B. L. Waldron, K. P. Vogel, J. D. Berdahl, M. R. Haferkamp, K. B. Jensen, T. A. Jones, R. Mitchell and B. K. Kindiger. 2007. Characterization of testing locations for developing cool-season grass species. Crop Sci. 47: 1004-1012.

Rose, I. V. L. W., M. K. Das and C. M. Taliaferro. 2008. A comparison of dry matter yield stability assessment methods for small numbers of genotypes of Bermuda grass. Euphytica, 164: 19-25.

Shafii, B., K. A. Mahler, W. J. Price and D.L. Auld. 1992. Genotype- environment interaction effects on winter rapeseed yield and oil content. Crop Sci. 32: 922-927.

Shukla, G. K. 1972. Some statistical aspects of partitioning genotype-environmental components of variability. Heredity 29: 237-245.

Wricke, G. 1962. Uber eine methode zur refassung der okologischen streubretite in feldversuchen, Flazenzuecht 47: 92-96.

Yan, W., L. A. Hunt, Q. Sheng and Z. Szlavnics. 2000. Genotype evaluation and mega-environment investigation based on the GGE biplot. Crop Sci. 40: 597-605.

Yan, W. and M. S. Kang. 2003. GGE Biplot Analysis: A Graphical Tool for Breeders, Geneticists and Agronomists. CRC Press, Boca Raton, FL.

Yates, F. and W. G. Cochran. 1938. The analysis of groups of experiments. J Agric. Sci. 28: 556-580. 
" ارزيابى برهمكنش زنوتيب در محيط.... رضا محمدى و همكاران، وجا، اب-1ها"

\title{
Evaluation of genotype $x$ environment interaction in durum wheat (Triticum turgidum var. durum L.) regional yield trials
}

\section{Mohammadi, R., ${ }^{1}$ B. Sadeghzadeh ${ }^{2}$ and M. Masoud Ahmadi ${ }^{3}$}

\begin{abstract}
Mohammadi, R., B. Sadeghzadeh and M. Masoud Ahmadi 2020. Evaluation of genotype $\times$ environment interaction in durum wheat (Triticum turgidum var. durum L.) regional yield trials. Iranian Journal of Crop Sciences. 22(1): 15-31. (In Persian).
\end{abstract}

The objective of this experiment was to analyze genotype $\times$ environment $(\mathrm{GE})$ interaction for grain yield of 20 durum wheat genotypes to identify the yield stability and adaptability of genotypes using GGE biplot method as well as some univariate stability statistics. The genotypes were evaluated in three rainfed stations of Sararood (Kermanshah), Maragheh and Shirvan, Iran under both rainfed and supplemental irrigation conditions in three cropping cycles from 2015 to 2018. Combined analysis of variance showed significant differences among the genotypes, environments and GE interaction effects. The environment effect was accounted for the $81.9 \%$ followed by GE interaction for $5.2 \%$ and genotype for $2.1 \%$ of total sum ofsquare (TSS). The large size of the GE interaction variance relative to genotype, suggests the possible existence of sub-environmental groups and genotypes with high grain yield and specific adaptation. Mean grain yield of genotypes across all environments was $2649 \mathrm{~kg} \cdot \mathrm{ha}^{-1}$, and 2212 and $3303 \mathrm{~kg} \cdot \mathrm{ha}^{-1}$ under rainfed and supplemental irrigation conditions, respectively. The highest mean yield was observed for breeding line G15 (2622 kg.ha $\left.{ }^{-1}\right)$ under rainfed conditions, and G3 (3744 kg.ha $\mathrm{h}^{-1}$ ) under supplemental irrigation conditions. The GGE biplot analysis could differentiate environments to sub-environmental groups with top yielding genotypes. According to GGE biplot, breeding lines G14, G15, G8, G16 and G11 were identified as ideal genotypes with high mean grain yield and yield stability performance. Based on stability parameters the high yielding breeding line G14 identified to have the most stable grain yiled. The environments belonged to Maragheh location with higher "discriminativeness and representativeness" ability was found as ideal location for evaluation of winter durum wheat germplasm. The results also showed genetic gains for high grain yield and yield stability for durum wheat breeding program under cold and temperate cold dryland conditions of Iran.

Key words: Adaptability, Durum wheat, Genotypexenvironment interaction, GGE biplot andYield stability.

Received: April, $2019 \quad$ Accepted: August, 2019

1. Associate Prof., Dryland Agricultural Research Institute, Sararood Branch, Agricultural Research, Education and Extension Organization, AREEO, Kermanshah, Iran (Corresponding author) (Email: r.mohammadi@areeo.ac.ir)

2. Associate Prof., Dryland Agricultural Research Institute, Agricultural Research, Education and Extension Organization, AREEO, Maragheh, Iran

3. Instructor., Agricultural and Natural Resources Research and Education Center of Northern Khorasan Agricultural Research, Education and Extension Organization, AREEO, Bojnourd, Iran 